\title{
DYNAMICS OF THE FEEDING ECOLOGY OF SELECTED FISH SPECIES FROM THE OKAVANGO RIVER DELTA, BOTSWANA
}

\author{
Ketlhatlogile MOSEPELE $^{1 *}$, Belda MOSEPELE ${ }^{1}$, Piotr WOLSKI ${ }^{1}$, and Jeppe KOLDING ${ }^{2}$ \\ ${ }^{1}$ Okavango Research Institute (University of Botswana), Maun, Botswana \\ ${ }^{2}$ Department of Biology, University of Bergen, Bergen, Norway
}

Mosepele K., Mosepele B., Wolski P., Kolding J. 2012. Dynamics of the feeding ecology of selected fish species from the Okavango River delta, Botswana. Acta Ichthyol. Piscat. 42 (4): 271-289.

Background. This study contributes to the understanding of the potential impact of changes in flooding patterns and (potential) fish production as a consequence of upstream developments in floodplain systems. Therefore, stomachs of eight fish species from the Okavango Delta were analysed to evaluate the feeding ecology of floodplain fish (and the effect of seasonal flooding), using the delta as a case study.

Materials and methods. In total, 2101 fish stomachs of eight species, representing six families, were collected (in all seasons) from the delta using experimental fishing nets, from 2004 to 2009. Frequency of occurrence, Levin's diet breadth index, Pianka's overlap index, trophic levels, and Bray-Curtis similarities were used to evaluate feeding preferences. Detrended correspondence analysis was used to study temporal variations in diet. Multiple linear regressions were used to determine the influence of flooding on diet. ANOVA and MANOVA were used to determine the level of significance among variables, while LSD post hoc analysis revealed the source of significance.

Results. Cluster analysis and Pianka's index highlighted inter- and intra-specific competition for food among different species and age classes, ANOVA highlighted dynamic changes in inter- and intra-specific trophic level partitioning, while detrended analysis showed that the terrestrial environment is subsidizing the aquatic environment. Regression analysis showed that Schilbe intermedius diet was driven by discharge $(F=7.03 ; P=0.045$; $\left.R^{2}=0.58\right)$ while that of Marcusenius macrolepidotus was driven by water depth $\left(F=25.88 ; P=0.04 ; R^{2}=0.93\right)$. Conclusion. The terrestrial-aquatic ecotone is important in fish growth of seasonal floodplains. Energy uptake is optimised through cannibalism to ensure species survival. Furthermore, species inter-relations are dynamic due to variations in food availability driven by seasonal flooding, which shortens and lengthens the food chain periodically. This dynamic relation is pronounced at low floods when predation and competition increases within the fish community. The evidence from this study has shown that predation, cannibalism, inter- and intra-specific competition are regulating factors in floodplain fish communities, driven by seasonal flooding.

Keywords: trophic level, resource partitioning, flood pulse, seasons, cannibalism

\section{INTRODUCTION}

Floodplain fisheries are considered to be some of the most productive ecosystems in the tropics (Welcomme 1979, Junk et al. 1989) and appear to take advantage of most of the biological principles for high productivity. They are fluvial, shallow and unstable, continuously oscillating, generally but not always with a high predictability between a terrestrial and an aquatic phase, and with a high external nutrient loading. Combined with high insolation and temperatures, the basis for primary- and higher order productivity in these areas is optimal (Kolding and van Zwieten 2005). Tropho-dynamic relations such as energy flow, predation, intra- and inter-specific competition determine community structure (Begon and Mortimer 1986, Ricklefs 1990) in conjunction with abiotic factors
(Claessen et al. 2004). Dynamic species interactions also result in cannibalism which Claessen et al. (2004) describe as a "short-circuited predator-prey system" where individuals ensure their survival by opportunistically preying on juveniles. Therefore, studying these factors is essential towards assessing the stability of fish food web structure (Ney 1993) in (fluctuating) floodplain systems.

Most floodplain fish species undergo horizontal and vertical migrations due to seasonal flooding (LoweMcConnell 1987). These migrations are an integral stage in the life history of floodplain fish and facilitate the transport of nutrients from nutrient rich floodplains into the more oligotrophic riverine system (Hoeinghaus et al. 2006). This dynamic nutrient flow, characterised by a pulsing system (Odum 1994) is based on the flood-pulse concept (Junk et

\footnotetext{
* Correspondence: Dr. Ketlhatlogile Mosepele, University of Botswana, Okavango Research Institute (ORI), Private Bag 285. Maun, Botswana, phone (direct): +(267) 681 7228, phone (switchboard): +(267) 686 1833, fax: +(267) 686 1835, e-mail: kmosepele@ori.ub.bw.
} 
al. 1989), which suggests that periodic flooding in floodplain systems is a natural event to which biological populations are adapted (Odum and Barret 2005). This periodic flooding produces "boom and bust" (Bunn et al. 2006) conditions which provide key ingredients for floodplain fish production (de Graaf 2003). Therefore, many floodplain fish species migrate as a response to seasonal flooding and resource availability (Lowe-McConnell 1987, Roach et al. 2009). Ultimately, the resultant terrestrial-aquatic ecotone in pulsing floodplain systems facilitates high fish biomass production (Eberle and Stanford 2010).

This study used several techniques to establish dynamics in the feeding ecology of several Delta species in relation to the flood pulse and to also highlight trophic inter-relations among different species. Merron and Bruton (1988) conducted the most comprehensive diet studies in the Delta using the volumetric method. However, Hyslop (1980) argues that this univariate approach can underestimate the relative importance of small food items. Also, Merron and Bruton (1988) give a detailed qualitative analysis of the feeding ecology of selected species in relation to the flood pulse but without quantitative analyses to establish the "flood-pulse vs. feeding" relation that has been done in other floodplain systems. Quantification of diet is important, because it helps to identify the roles of predators in ecosystems (Baremore et al. 2010). Therefore, using several techniques (to study fish diet) agrees with Marshall and Elliot (1997) who argued that a variety of techniques should be used to assess fish feeding behaviour due to various weaknesses inherent in all the different methods. Additionally, each approach provides different insights into feeding habits (Baldoa and Drake 2002). Testing this approach in the Okavango Delta will contribute to the knowledge on floodplain fish feeding ecology and factors structuring these populations in dynamic systems. Furthermore, this study also investigates the intrinsic importance of the aquatic-terrestrial system interface (the so called ecotone) dynamics for fish productivity in flood-pulsed floodplains. It subsequently increases the understanding of why shallow fluctuating tropical wetlands are among the most productive ecosystems (Junk 1996, Zalewski et al. 2001).

The main aim of this study was to establish the effect of the flood pulse on floodplain fish feeding ecology, such as spatio-temporal variations, (potential) inter- and intraspecific competition. Establishing this relation would then highlight the role of Junk's et al. (1989) flood pulse concept on floodplain fish ecology.

\section{MATERIALS AND METHODS}

Study area. Fish samples for diet analysis were collected from the Upper Delta, Lower Delta, sump lakes (Lake Ngami), and outlet rivers (Boteti; see Fig. 1). The habitats sampled within each area were riverine habitats; seasonally inundated floodplains and lagoon habitats, except for Lake Ngami which is a shallow sump lake on the edge of the Delta (see Table 1). The Okavango Delta is a flood-driven, pulsing system fed with water annually from the Angolan highlands (Ramberg et al. 2006) whose surface area changes annually depending on the magnitude of hydrological inputs (Wolski et al. 2006). The flood waters arrive in the Panhandle portion of the Delta, peaking in this region between April and May (Wolski and Murray-Hudson 2005, Wolski et al. 2006) and may take several months to traverse the Delta's breadth peaking as late as August in Maun, i.e., may result in a time lag between the floods' arrival at the panhandle and their arrival at different parts of the Delta (Wolski and MurrayHudson 2005).

Sampling. Two kinds of experimental fishing nets were used to collect fish specimens for diet studies in several areas around the Delta, three days per month from 2005 until 2008. Nets were set every evening at approximately $1800 \mathrm{~h}$ and removed in the morning at approximately $0600 \mathrm{~h}$ (12 h soaking time). The net mesh size used ranged from $8 \mathrm{~mm}$ to $150 \mathrm{~mm}$ stretched mesh. After removal from the nets, each fish specimen was identified to species level and total length (TL) measured of each fish specimen selected for diet analysis. Fish were then divided into 5-cm length classes. Fish lengths were then transformed into age using the von Bertalanffy growth function (VBGF) similar to Froese and Binohlan (2000). The VBGF parameters used in this study were derived by Mosepele and Nengu (2004) in their analysis of selected species from the Okavango Delta.

Similar to Watanabe et al. (2003), after removal, fish guts were preserved in $70 \%$ alcohol before laboratory analyses. Prey items were separated into major groups where aquatic macro-invertebrate taxa were identified to order only due to high degree of digestion. Where possible, fish were identified to species level or otherwise classified as "fish" (when they were too digested to identify them), plant material was identified to general groups like "seeds, tree bark, grass, etc.", while terrestrial insects were generally classified as one group (apart from ants, Arachnidae and arthropods). The vacuity index (percentage of empty stomachs) was also calculated. Trophic levels were estimated using TrophLab (Pauly et al. 2000) based on the percentage contribution (by weight) of each prey item to the diet. Similar to Stergiou and Karpouzi (2002), we used the "Diet composition" routine in the model to estimate the trophic levels. Fish were then classified according to Stergiou and Karpouzi's (2002) fractional trophic levels as:

- Pure herbivores (TROPH = 2.0-2.1);

- Omnivores with preference for plants $(2.1<\mathrm{TROPH}<2.9)$; - Omnivores with preference for animals $(2.9<\mathrm{TROPH}<3.7)$; and

- Carnivores with preference for fish $(3.7<\mathrm{TROPH}<4.5)$.

Univariate analyses. Frequency of occurrence (FO), which is the simplest approach to conducting diet analysis (Hyslop 1980) and has consequently been used extensively (Vaz et al. 1999, Agostinho et al. 2003, Watanabe et al. 2003, Navia et al. 2007) was the main index used in this study. Feeding strategy was determined through Levin's diet breadth index $\left(B_{\mathrm{i}}\right)$ in a manner similar to 


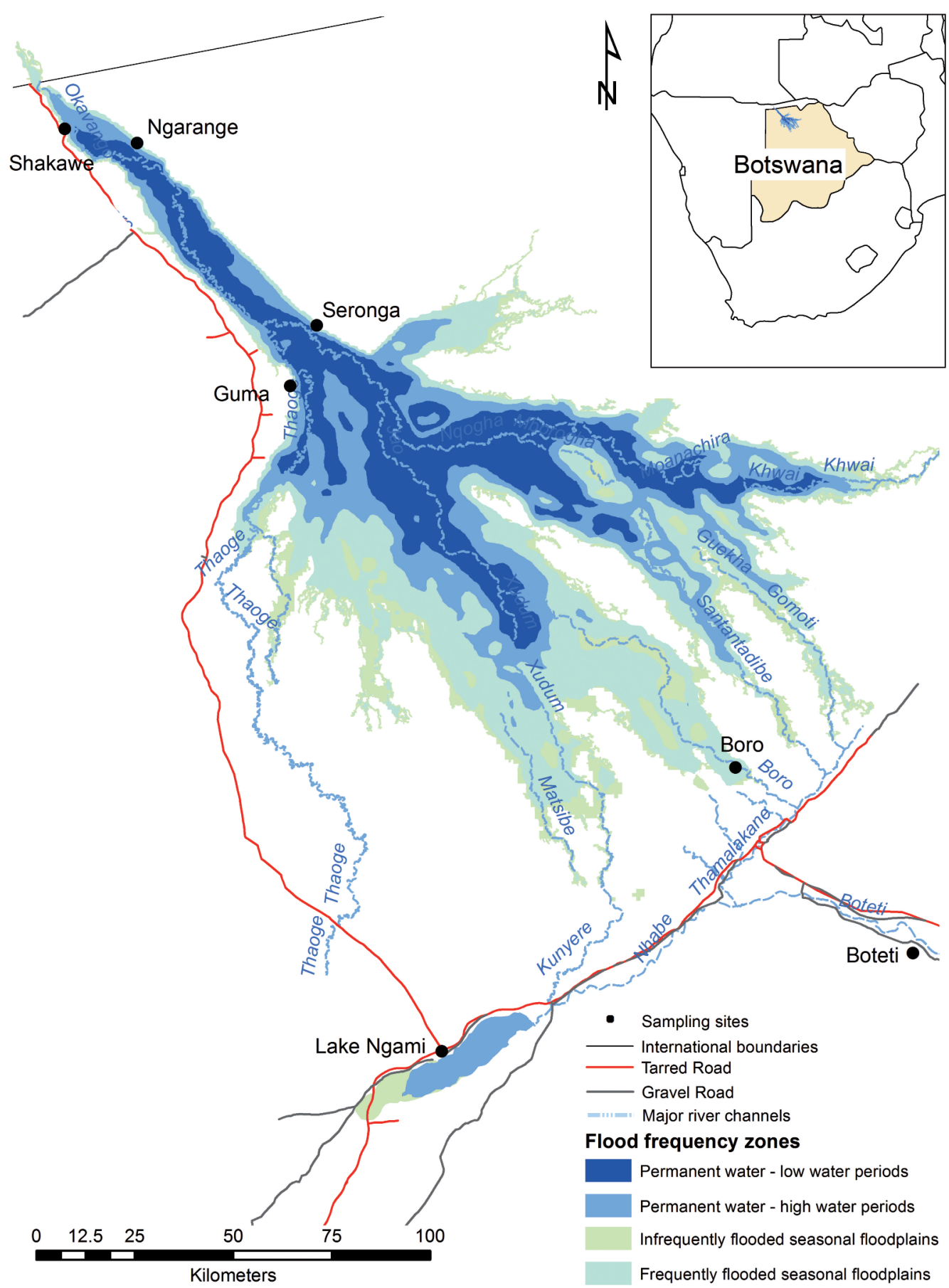

Fig. 1. Sampling areas in the Okavango River delta where fish specimens were sampled for fish diet analysis

Rosas-Alayalo et al. (2002), where low values $\left(1<B_{\mathrm{i}}<2\right)$ indicated predators with specialised diet, medium values $(2.1<\mathrm{Bi}<3)$ indicated predators with less specialised diet, while high values $\left(B_{\mathrm{i}}>3\right)$ indicated generalist predators. This index has been widely used to study shifts in diet of many fish species (Feinsinger et al. 1981, Vázquez et al. 2008, Baremore et al. 2010).

Multivariate analyses. Pianka's Overlap Index (POI), implemented in Ecosim 7 routine (Gotelli and Entsminger 2007) was used to determine the level of spatial and temporal variations in diet for selected species (Rosas-Alayola et al. 2002, Agostinho et al. 2003, Navia et al. 2007) where values exceeding 0.6 were considered to be biologically significant (Navia et al. 2007). Ecosim 7 was then used to test the significance of the overlap using randomisation procedures. Multivariate analyses were performed using Primer (Clarke and Gorley 2001). Prey items were grouped by order (or class, depending on the ease at which the digested items could be identified) and then root transformed similar to Baldoa and Drake (2002). Subsequently, Bray-Curtis coefficients were calculated providing a measure of dietary overlap as observed by Marshall and Elliot (1997). Thereafter, cluster analysis was employed using the group-average link- 
ing approach based on Bray-Curtis similarities to explore potential intra- and inter-specific competition for food among several selected species, across different age classes. The importance of different food items to different feeding groups was assessed using SIMPER analysis (Sá et al. 2006) where data were standardised, then squareroot transformed and cut-off for low contributions set at 90\% (based on Bray-Curtis mean similarity).

Temporal variations in diet were determined through a detrended correspondence analysis (DCA-DECORANA) in PC-ORD (McCune and Mefford 1999). Only the scores of the axis with eigenvalues higher than 0.2 were retained for analysis, similar to Corrêa et al. (2009), while the rest were discarded. A multiple linear regression was then conducted between the diet scores from axis 1 (which represents frequency of occurrence of food items) and water depth (and discharge) to explore the influence of hydrological conditions on feeding behaviour of Schilbe intermedius
Rüppell, 1832 (Schilbeidae) and Marcusenius macrolepidotus (Peters, 1852) (Mormyridae). According to Mosepele et al. (2011) these two species are the most dominant in the Delta's fish community. They were also the most abundant in the samples collected during this study which therefore allowed for detailed analysis. Due to data paucity for Clarias gariepinus (Burchell, 1822) (Clariidae) and Tilapia rendalli (Boulenger, 1897) (Cichlidae), Principal Component Analysis (PCA in PC-ORD) was used instead of the DCA-DECORANA routine.

Other statistical analyses. Significance levels for all statistical tests were set at 95\% confidence level. Multiple linear regressions were conducted to determine the relation between feeding indices and flooding parameters (e.g., water depth and discharge). Analysis of Variance (ANOVA) and Multivariate Analysis of Variance (MANOVA) (using STATISTICA ${ }^{\circledR}$ software) were used to determine and test the level of significance between

Brief description and location of the various study sites at the Okavango River delta, Botswana

Table 1

\begin{tabular}{|c|c|c|c|c|}
\hline SA & Site & \multicolumn{2}{|c|}{ Coordinates } & Description \\
\hline \multirow{4}{*}{ 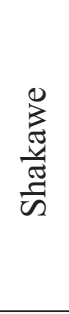 } & 1 & $18^{\circ} 16^{\prime} 27.8^{\prime \prime} \mathrm{S}$ & $21^{\circ} 48^{\prime} 05.6^{\prime \prime} \mathrm{E}$ & $\begin{array}{l}\text { Backwater channel dominated by papyrus (Cyperus papyrus) } \\
\text { and common reed (Phragmites australis) }\end{array}$ \\
\hline & 2 & $18^{\circ} 20^{\prime} 29.0^{\prime \prime} \mathrm{S}$ & $21^{\circ} 50^{\prime} 10.2^{\prime \prime} \mathrm{E}$ & $\begin{array}{l}\text { Main river channel dominated by papyrus, hippo grass } \\
\text { (Echinochloa stagnina) and common reed }\end{array}$ \\
\hline & 3 & $18^{\circ} 25^{\prime} 59.7^{\prime \prime} \mathrm{S}$ & $21^{\circ} 58^{\prime} 18.4^{\prime \prime} \mathrm{E}$ & Side channel from main river. Hippo grass on littoral area \\
\hline & 4 & $18^{\circ} 26^{\prime} 22.8^{\prime \prime} \mathrm{S}$ & $21^{\circ} 54^{\prime} 41.6^{\prime \prime} \mathrm{E}$ & $\begin{array}{l}\text { Lagoon connected to the main channel. The common reed } \\
\text { on littoral area }\end{array}$ \\
\hline \multirow{4}{*}{$\underset{\Xi}{\Xi}$} & 1 & $18^{\circ} 57^{\prime} 42.0^{\prime \prime} \mathrm{S}$ & $22^{\circ} 23^{\prime} 08.7^{\prime \prime} \mathrm{E}$ & $\begin{array}{l}\text { Next to inflow channel into lagoon dominated by common } \\
\text { reed and papyrus }\end{array}$ \\
\hline & 2 & $18^{\circ} 57^{\prime} 42.0^{\prime \prime} \mathrm{S}$ & $22^{\circ} 23^{\prime} 08.7^{\prime \prime} \mathrm{E}$ & $\begin{array}{l}\text { Centre of lagoon next to a bed of water caltrop (Trapa natans) } \\
\text { and papyrus }\end{array}$ \\
\hline & 3 & $18^{\circ} 57^{\prime} 42.9^{\prime \prime} \mathrm{S}$ & $22^{\circ} 23^{\prime} 13.2^{\prime \prime} \mathrm{E}$ & $\begin{array}{l}\text { Centre of lagoon next to a bed of Pycreus mundii, papyrus } \\
\text { and Ceratophyllum sp. beds }\end{array}$ \\
\hline & 4 & $18^{\circ} 58^{\prime} 01.1^{\prime \prime} \mathrm{S}$ & $22^{\circ} 22^{\prime} 40.5^{\prime \prime} \mathrm{E}$ & $\begin{array}{l}\text { Next to the outflow channel from the lagoon dominated by } \\
\text { papyrus }\end{array}$ \\
\hline \multirow{3}{*}{ 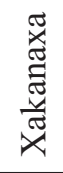 } & 1 & $19^{\circ} 10^{\prime} 07.0^{\prime \prime} \mathrm{S}$ & $23^{\circ} 23^{\prime} 38.9^{\prime \prime} \mathrm{E}$ & Centre of the lagoon next to a Trapa natans mat \\
\hline & 2 & $19^{\circ} 10^{\prime} 07.7^{\prime \prime} \mathrm{S}$ & $23^{\circ} 23^{\prime} 38.9^{\prime \prime} \mathrm{E}$ & On the littoral region of the lagoon next to common reed \\
\hline & 3 & $19^{\circ} 09^{\prime} 22.4^{\prime \prime} \mathrm{S}$ & $23^{\circ} 16^{\prime} 12.2^{\prime \prime} \mathrm{E}$ & River channel flowing into the lagoon next to common reed \\
\hline \multirow{4}{*}{ 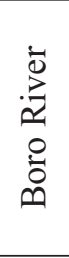 } & 1 & $19^{\circ} 32^{\prime} 57.0^{\prime \prime} \mathrm{S}$ & $23^{\circ} 10^{\prime} 38.8^{\prime \prime} \mathrm{E}$ & On the fringe of the river channel next to papyrus \\
\hline & 2 & $19^{\circ} 32^{\prime} 57.0^{\prime \prime} \mathrm{S}$ & $23^{\circ} 10^{\prime} 38.8^{\prime \prime} \mathrm{E}$ & Floodplain habitat, dominated mostly by hippo grass \\
\hline & 3 & $19^{\circ} 31^{\prime} 44.2^{\prime \prime} \mathrm{S}$ & $23^{\circ} 10^{\prime} 57.1^{\prime \prime} \mathrm{E}$ & $\begin{array}{l}\text { Floodplain river channel dominated mostly by hippo grass } \\
\text { and sedges (plants from family Cyperaceae) }\end{array}$ \\
\hline & 4 & $20^{\circ} 12^{\prime} 99.89^{\prime \prime} \mathrm{S}$ & $23^{\circ} 15^{\prime} 15.93^{\prime \prime} \mathrm{E}$ & Various sites in the lagoon. Open water and littoral habitats \\
\hline $\mathrm{LN}$ & 1 & $20^{\circ} 27^{\prime} 43.25^{\prime \prime} \mathrm{S}$ & $22^{\circ} 47^{\prime} 55.08^{\prime \prime} \mathrm{E}$ & Various sites in the lake. Open water and littoral habitats \\
\hline \multirow{3}{*}{$\begin{array}{l}\dot{v} \\
\dot{\overrightarrow{0}} \\
\ddot{0} \\
0\end{array}$} & 1 & $20^{\circ} 09^{\prime} 10.16^{\prime \prime} \mathrm{S}$ & $23^{\circ} 39^{\prime} 26.76^{\prime \prime} \mathrm{E}$ & $\begin{array}{l}\text { Open water and littoral habitats dominated by common reed } \\
\text { and papyrus }\end{array}$ \\
\hline & 2 & $20^{\circ} 78^{\prime} 0.54^{\prime \prime} \mathrm{S}$ & $23^{\circ} 27^{\prime} 40.14^{\prime \prime} \mathrm{E}$ & $\begin{array}{l}\text { Open water and littoral habitats dominated by common reed } \\
\text { and papyrus }\end{array}$ \\
\hline & 3 & $20^{\circ} 13^{\prime} 19.70^{\prime \prime} \mathrm{S}$ & $24^{\circ} 08^{\prime} 16.76^{\prime \prime} \mathrm{E}$ & $\begin{array}{l}\text { Open water and littoral habitats dominated by common reed } \\
\text { and papyrus }\end{array}$ \\
\hline
\end{tabular}

$\mathrm{SA}=$ study area, $\mathrm{LN}=$ Lake Ngami. 
variables, while Fischer's Least Significance Difference (LSD) post hoc analysis was conducted to determine the source of the significance among the variables.

\section{RESULTS}

General diet description. In total, 2101 fish stomachs of eight species, representing six fish families, sampled from 2004 to 2009, were collected and analysed for diet. The largest fish specimen collected was Clarias gariepinus $(464 \mathrm{~mm})$ while the smallest was Brycinus lateralis (Boulenger, 1900) (Alestidae) (111 mm; see Table 2). $B$. lateralis had the highest vacuity index $(40 \%)$ while none was observed for Oreochromis andersonii (Castelnau, 1861) (Cichlidae) (Table 2). The highest richness of prey groups was observed for Schilbe intermedius while the lowest was observed for cichlids (Oreochromis andersonii and Tilapia rendalli) and Hepsetus odoe (Bloch, 1794) (Hepsetidae). Clarias ngamensis Castelnau, 1861 (Clariidae) had the highest diet breadth index, suggesting a more general feeding strategy than the other species, while $H$. odoe had the most specialised feeding strategy (see Table 2). Algae is a key diet food (based on weight) for three fish species (C. gariepinus, $M$. macrolepidotus, and $T$. rendalli), while detritus is key diet item for two fish species (C. ngamensis and $O$. andersonii). Fish is a key food item for $S$. intermedius and $H$. odoe while seeds dominate B. lateralis diet (see Table 3 ). Fish and algae are the most frequently eaten food items (by three fish species each as shown in Table 3), while detritus and Odonata are the most frequently eaten food item by one fish species each. Cannibalism was observed in S. intermedius, C. gariepinus, and C. ngamensis.

Competition (intra- and inter-specific). Classification based on dietary overlap using Bray-Curtis similarities revealed two major feeding guilds (Fig. 2) at the 34\% similarity level. Guild 1 (piscivores) is composed of two age classes of $H$. odoe $(1+$ and $2+), 1+C$. ngamensis and $T$. rendalli, and $3+S$. intermedius. All the other species across their different age groups are grouped together into Guild 2 (algavores). Dietary separation between these two guilds was highly significant (ANOSIM: $r=0.616$, $P=0.001)$. Furthermore, three sub-guilds are discernable within Guild 2 at between the $50 \%-60 \%$ similarity levels. Sub-guild 2A (omnivorous on fish, detritus and vegetation) is composed of $1+$ and $2+S$. intermedius (at approximately $65 \%$ similarity) and $2+$ and $3+C$. ngamensis (at approximately $70 \%$ similarity) and $2+$ and $3+C$. gariepinus (at approximately $80 \%$ similarity). Sub-guild $2 \mathrm{~B}$ (omnivorous on algae, Diptera, and vegetation) is composed of all the age classes of M. macrolepidotus (e.g., 1+-3+) and $0+$ $B$. lateralis. Finally, sub-guild $2 \mathrm{C}$ (omnivorous on algae, vegetation and fish) is composed of $0+$ and $1+O$. andersonii, and $0+, 1+T$. rendalli.

The most "potentially" intense intra-specific competition for food was found between the $H$. odoe age groups $(\mathrm{POI}=0.99)$ while the least intense intra-specific competition was observed between $1+$ and $3+S$. intermedius $(\mathrm{POI}=0.61)$. Similarly, the most intense inter-specific competition for food was observed between $1+T$. rendal$l i$ and $C$. ngamensis (POI $=0.96)$, while the least interspecific competition (but still biologically significant) was observed between $2+C$. ngamensis and $3+$ $C$. gariepinus $(\mathrm{POI}=0.62)$. There was virtually no competition for food between $1+H$. odoe and $2+$ M. macrolepidotus (POI $\approx 0.02)$, and in fact $H$. odoe preys on M. macrolepidotus (Table 3).

Despite the dietary classification of the different species into two major feeding guilds, there was a signif-

Summary statistics illustrating the mean size, diet breadth and key food items for fish species sampled from the Okavango River delta, Botswana

\begin{tabular}{|c|c|c|c|c|c|c|c|c|c|c|}
\hline Species & $\mathrm{TL}[\mathrm{mm}]$ & $V$ & $n$ & $B$ & $\operatorname{TrL}$ & PGN & KPG & FP & Key diet taxon & Key fish species \\
\hline $\begin{array}{l}\text { Schilbe } \\
\text { intermedius }\end{array}$ & $192 \pm 58$ & 27 & 792 & 5.78 & $3.69 \pm 0.59$ & 30 & Fish & OPA & Barbus spp. & $\begin{array}{l}\text { B. } \\
\text { thamalakanensis }\end{array}$ \\
\hline $\begin{array}{l}\text { Marcusenius } \\
\text { macrolepidotus }\end{array}$ & $182 \pm 56$ & 24 & 460 & 5.62 & $2.91 \pm 0.34$ & 21 & Diptera & OPA & Chironomidae & $\begin{array}{l}\text { Aplocheilichthys } \\
\text { spp. }\end{array}$ \\
\hline $\begin{array}{l}\text { Brycinus } \\
\text { lateralis }\end{array}$ & $111 \pm 25$ & 40 & 195 & 7.44 & $2.92 \pm 0.45$ & 18 & Odonata & OPA & Libellulidae & - \\
\hline $\begin{array}{l}\text { Clarias } \\
\text { gariepinus }\end{array}$ & \pm 142 & 24 & 148 & 5.29 & 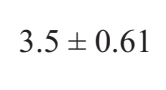 & 23 & Detritus & OPA & Det & $\begin{array}{l}\text { Tilapia } \\
\text { sparrmanii }\end{array}$ \\
\hline C. ngamensis & $396 \pm 106$ & 14 & 185 & 10.95 & $2.40 \pm 0.29$ & 22 & Vegetation & OPP & Grass & Clarias spp. \\
\hline $\begin{array}{l}\text { Oreochromis } \\
\text { andersonii }\end{array}$ & $205 \pm 61$ & 0 & 104 & 3.18 & $2.10 \pm 0$ & 7 & Algae & OPP & Algae & Barbus spp. \\
\hline Tilapia rendalli & $163 \pm 63$ & 24 & 65 & 2.62 & $2.18 \pm 0.21$ & 7 & Algae & OPP & Algae & - \\
\hline Hepsetus odoe & $275 \pm 64$ & 37 & 152 & 1.27 & $4.44 \pm 0.79$ & 16 & Fish & $\mathrm{CPF}$ & Barbus spp. & $\begin{array}{l}\text { B. } \\
\text { thamalakanensis }\end{array}$ \\
\hline
\end{tabular}

Values of total length (TL) and trophic level are mean \pm standard deviation; $V=$ vacuity index; $n=$ total number of stomach sampled; $B=$ Levin's diet breadth index; TrL = fractional trophic level; PGN = number of prey groups; KPG $=$ key prey groups based on frequency of occurrence; $\mathrm{FP}=$ food preference; OPA = omnivores with preference for animals; OPP = omnivores with preference for plants; $\mathrm{CPF}=$ carnivores with preference for fish. 


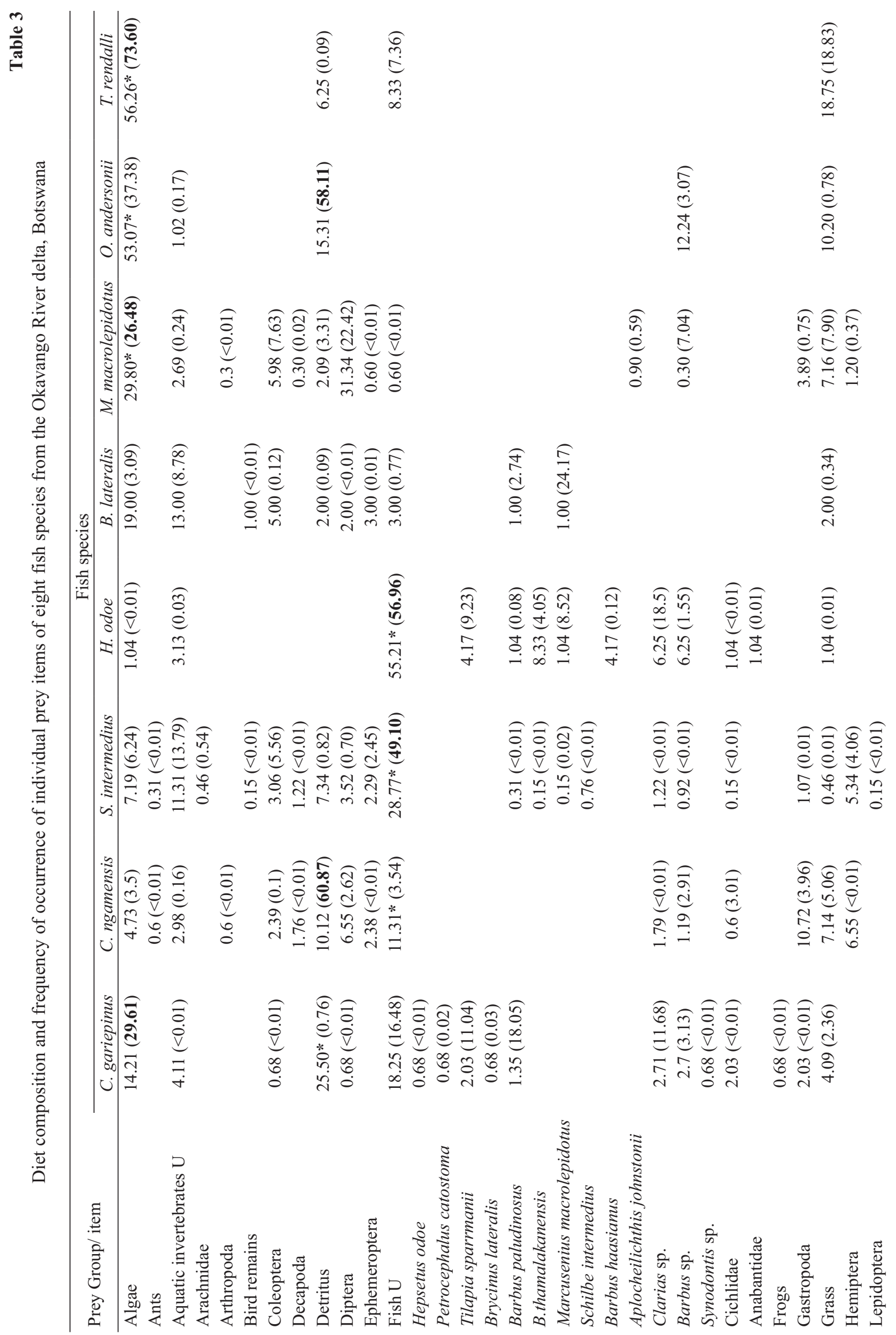




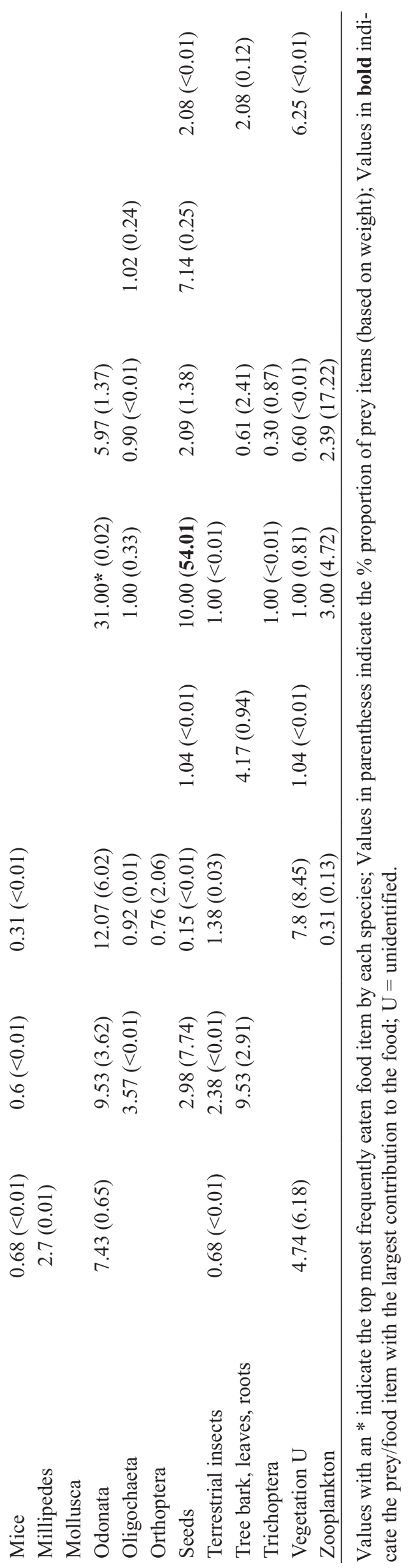




\section{Pianka's Overlap Index (Key Results)}

-2+ vs. $1+H$. odoe $=0.99: 1+$ vs. $3+$ S. intermedius $=0.61: 1+T$. rendalli vs. $1+C$. ngamensis $=0.96$

$.2+$ C. ngamensis. vs. 3+ C. gariepinus $=0.62$ : $1+H$. odoe vs. $2+$ M. macrolepidotus $=0.02$

Toph level analysis (Key Results)

-1+M. macrolepidotus vs. $1+, 2+, 3+S$. intermedius $=\mathrm{p}<0.05$

- $1+, 2+H$. odoe vs. all the other species (i.e. $3+C$. ngamensis, $2+C$. gariepinus, $2+S$. intermedius,

$1+S$. intermedius, etc $)=p<0.05: 1+, 2+H$. odoe vs. $3+S$. intermedius $=p>0.05$

$\bullet 1+M$. macrolepidotus vs. $1+, 3+S$. intermedius $=\mathrm{p}<0.05: 1+, 2+\& 3+S$. intermedius vs. $1+, 0+$

0 . andersonii \& $0+, 1+T$. rendalli $=\mathrm{p}<0.05: 1+, 2+, 3+S$. intermedius vs. $3+C$. gariepinus $=p<0.05$

- 1+, 2+, 3+C. ngamensis vs. $2+, 3+S$. intermedius: $2+$ vs. $3+C$. gariepinus $=p<0.05: 1+$ vs. $2+, 3+$

S. intermedius $=p<0.05$

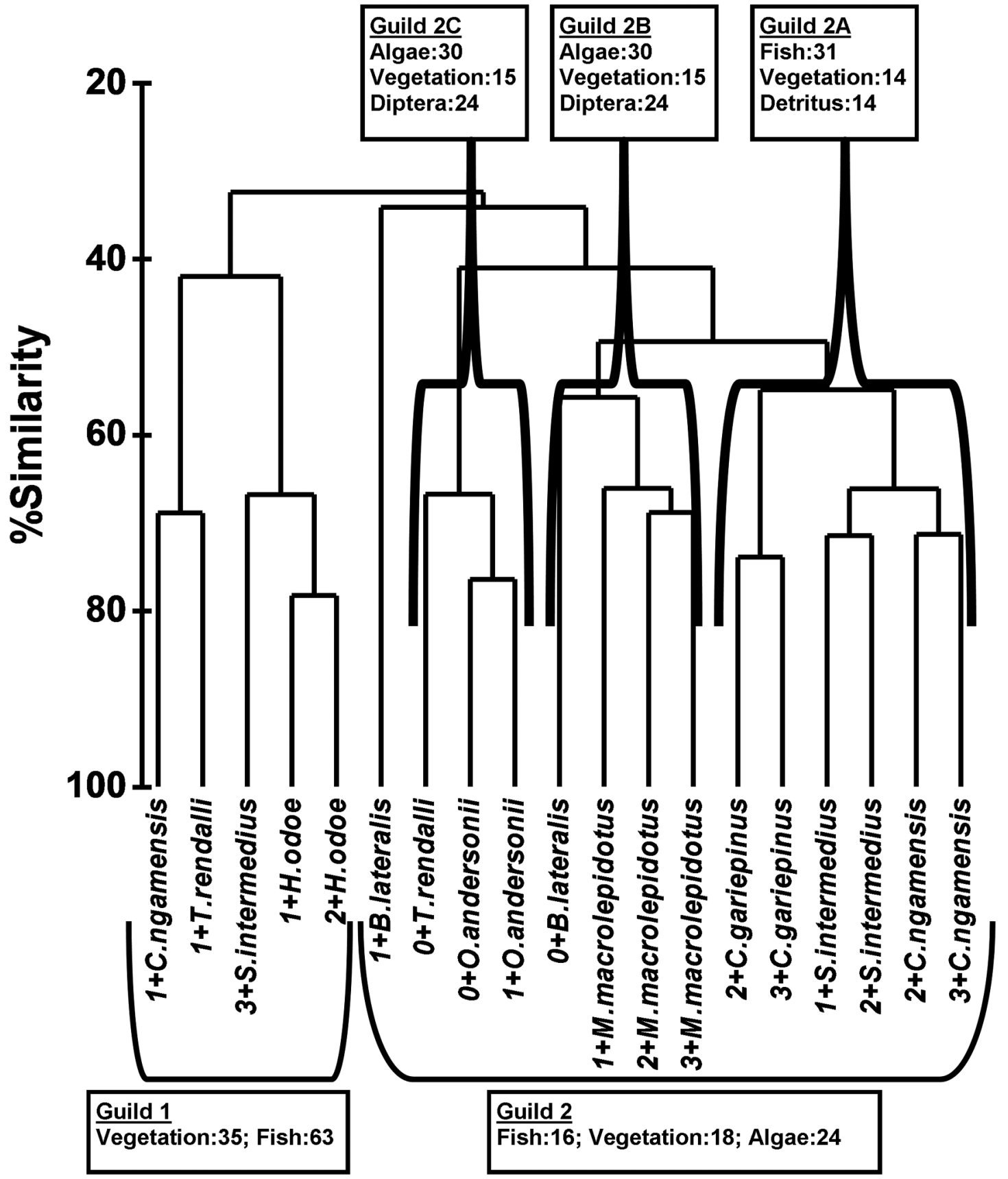

Fig. 2. Dendrogram using group-average linking on Bray-Curtis similarities of fish species sampled at the Okavango River delta across several size classes based on diet occurrence data; Information in text boxes refers to results from SIMPER analysis highlighting the $\%$ contribution of the respective food item to the diet of the particular feeding guild 
icant trophic partitioning among the different species and size classes (see Fig. 3), i.e., between $H$. odoe and all the other species in this study (ANOVA: $P<0.05$ ), with the exception of $3+S$. intermedius. Various permutations between the different size classes showed (inter-specific) trophic partitioning among the different species (e.g., 1+ M. macrolepidotus vs. $1+, 2+$, and $3+S$. intermedius; all age classes of $S$. intermedius vs. all age classes of $O$. andersonii and $T$. rendalli; all age classes of $S$. intermedius vs. $3+C$. gariepinus; all age classes of C. ngamensis vs. $2+$ and $3+S$. intermedius, etc.). Furthermore, the only (intra-specific) trophic separation observed in this study occurred between $2+$ vs. $3+C$. gariepinus, and between $1+S$. intermedius vs. $2+$ and $3+S$. intermedius (Fig. 2). These suggest ontogenetic feeding behaviour.

Spatial variations in food resource partitioning

Schilbe intermedius. Pseudo-habitat partitioning based on diet differences was observed in $1+S$. intermedius which were clustered into two feeding guilds at the $40 \%$ similarity level (Fig. 3), i.e., generalist predators from Boteti, Boro River and Xakanaxa, and specialist

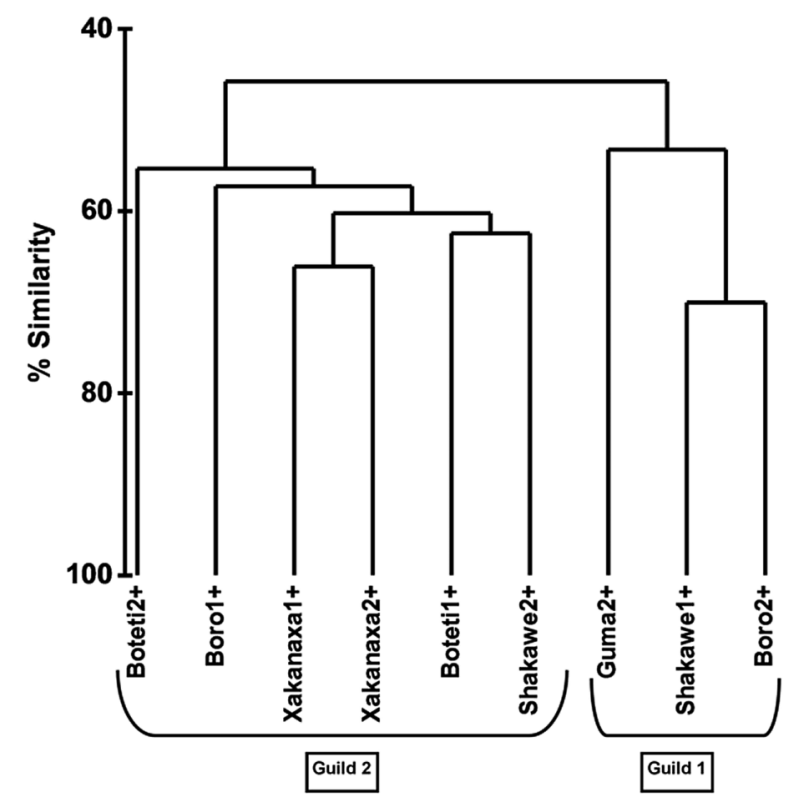

Fig. 3. Dendrogram illustrating pseudo-habitat partitioning (based on diet differences) of $1+$ and $2+$ Schilbe intermedius from five different areas of the Okavango River delta, based on diet analysis. 1+ refers to oneyear-old fish while $2+$ refers to two-year-old predators from Shakawe (Table 4). No significant trophic differences were found between 1+ (ANOVA: $P=0.22$, $\mathrm{DF}=4)$ and $2+($ ANOVA: $P=0.16, \mathrm{DF}=4) S$. intermedius among the sites.

$2+S$. intermedius were clustered into two major feeding guilds around the $45 \%$ similarity level. Guild 1 is composed of fish from Boteti, Shakawe, and Xakanaxa while Guild 2 includes fish from Boro River and Guma (Fig. 3) even though the diet differences were not significant (ANOSIM: $r=0.75, P=0.1$; see Table 4). Odonata, Hemiptera, and Diptera, respectively, contributed (cumulatively) $39 \%$ of the two guilds' dissimilarity with $2+$ S. intermedius from Boro River being specialist predators while those from the other areas were relatively generalist in their diet.

Marcusenius macrolepidotus. 1+ M. macrolepidotus were clustered into two feeding guilds around the 50\% similarity level using Bray-Curtis similarities (Fig. 4). Guild 1 was composed of fish from Boro (generalist predators: Table 4), Guma (specialist predators: Table 4), and Xakanaxa while Guild 2 consisted of fish from Boteti

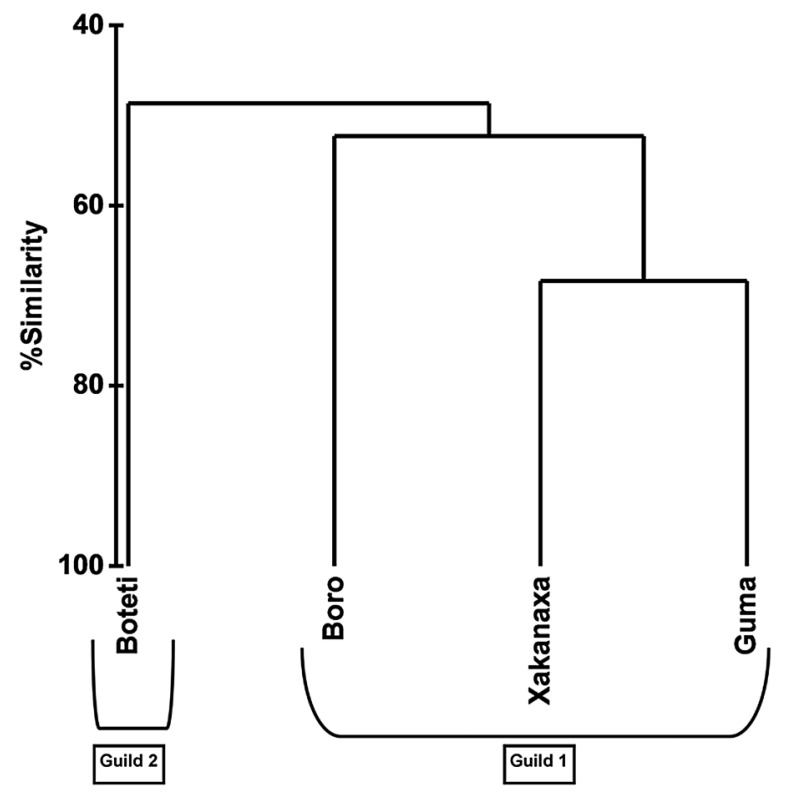

Fig. 4. Bray-Curtis similarity dendrogram, illustrating habitat partitioning on feeding behaviour of one-yearold Marcusenius macrolepidotus among several habitats in the Okavango River delta

Table 4

Diet breadth index illustrating feeding behaviour of two age classes of Schilbe intermedius and Marcusenius macrolepidotus among different areas

\begin{tabular}{lccccc}
\hline \multirow{2}{*}{ Species and age class } & \multicolumn{5}{c}{ Study area } \\
\cline { 2 - 6 } & Boteti & Shakawe & Boro River & Guma & Xakanaxa \\
\hline M. macrolepidotus 1+ & 2.99 & - & 7.00 & 2.41 & 4.35 \\
M. macrolepidotus 2+ & 3.55 & - & 4.18 & - & - \\
S. intermedius 1+ & 5.41 & 2.27 & 6.54 & - & 6.69 \\
S. intermedius 2+ & 3.47 & 3.75 & 2.62 & 3.84 & 6.38 \\
\hline
\end{tabular}


River (specialist predators: Table 4) only. No significant trophic partitioning (ANOVA: $P=0.61, \mathrm{DF}=3$ ) of $1+$ M. macrolepidotus was found among the four different areas.

$2+M$.macrolepidotus from Boro were generalist predators while those from Boteti were specialist predators (Table 4). No significant trophic partitioning between the two areas was found (ANOVA: $P=0.999, \mathrm{DF}=3$ ).
Diet variations with flood stage

DCA-DECORANA (and PCA for Tilapia rendalli and Clarias gariepinus) was used to evaluate changes in feeding behaviour of several floodplain fish species over various age groups in Boro River (Fig. 5). At floods' onset in the area, 1+ Schilbe intermedius fed on detritus and ants but switched to a diet consisting of algae, bees,
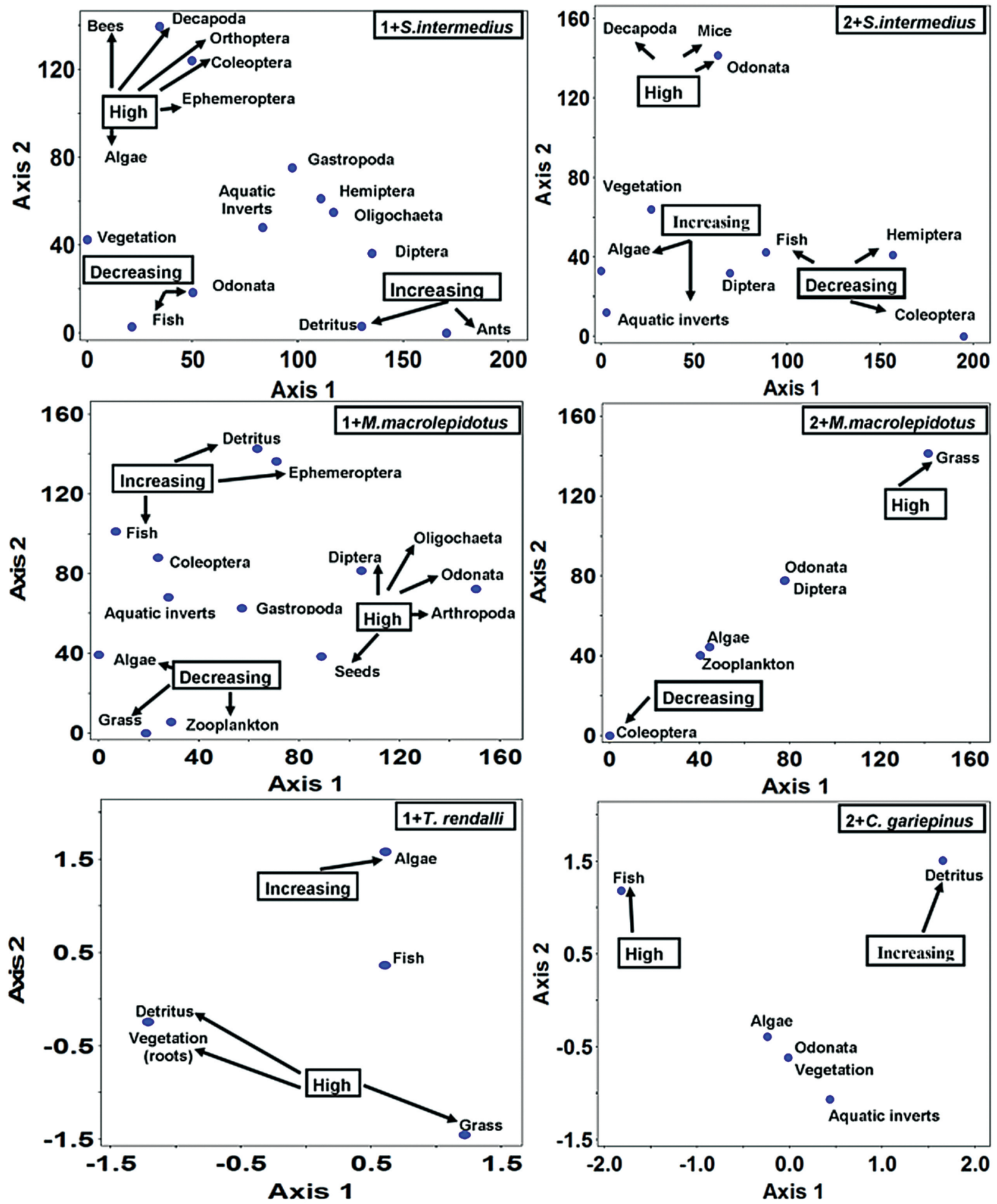

Fig. 5. DCA-DECORANA analysis (and PCA analysis for Tilapia rendalli and Clarias gariepinus) illustrating flood pulse induced diet shifts of selected fish species (different ages) in the Boro River seasonal floodplain (Note: the length of the arrows does not indicate the strength of the influence) 
Ephemeroptera, Coleoptera, Decapoda, and Orthoptera as the flood progressed. This diet then changed to fish and Odonata at decreasing water levels. Other diet items such as Diptera and Oligochaeta did not show any major seasonality. Similar diet shifts were observed for $2+S$. intermedius where algae and (unidentified) aquatic invertebrates were key food items at increasing water levels. This diet then switched to mice, Decapoda, and Odonata at peak floods and then changed to Hemiptera, fish, and Coleoptera at decreasing water levels.

Several diet shifts were also observed for $1+$ and $2+$ Marcusenius macrolepidotus in Boro (Fig. 5). The key items preyed by $1+$ fish at increasing water levels were detritus, Ephemeroptera, and fish, which then changed to Diptera, Odonata, Arthropoda, Oligochaeta and seeds at high water levels. Their diet then shifted to algae, zooplankton, and grass at decreasing water levels. Similarly, grass was the key food item at peak floods for $2+$ fish and they subsequently switched to Coleoptera at decreasing water levels. 1+ Tilapia rendalli fed more on algae at increasing water levels and switched to a diet dominated by detritus and vegetation (grass and tree roots) at peak floods. $2+$ Clarias gariepinus fed more on detritus at increasing water levels and switched to a diet dominated by fish at peak floods.

Bray-Curtis similarities were used to determine the resultant species interactions during different flood stages and feeding behaviour (Fig. 6) while SIMPER analysis was used to determine the key prey items in each guild. Two major feeding guilds (Bray-Curtis similarity) composed of piscivores and detritivores (SIMPER analysis) were identified in all the flood stages, except for the decreasing water level period where "piscivores" and "algivores" were the major feeding guilds. Based on SIM-
PER analysis, the relative contribution of fish to the "piscivorous" guild was lowest at peak floods (43\%), and highest at decreasing water levels (84\%). Similarly, while detritus contributed $100 \%$ to the diet of the "detritivorous" guild at peak floods, it only contributed $47 \%$ to this guild at increasing water levels. These changes were caused by variations in species interactions within these flooding seasons. While both $1+$ and $2+$ Hepsetus odoe belonged to the "piscivorous" guild throughout the different flooding stages, species such as 0+ Oreochromis andersonii moved in and out of this guild. Both age classes of $O$. andersonii were the only members of the "detritivorous" guild at peak floods. Moreover, fish were eaten by most species (and age classes) at peak floods than in the other two flood stages.

Trophic level and diet overlap dynamics were observed among and within the different species (Tables 5-6). Essentially, these observations suggest that generally, intra-specific competition for food was highest at decreasing water levels, while inter-specific competition was highest at increasing water levels.

Ecosim 7 analysis (using Pianka's niche overlap) revealed some significant (e.g., POI $>0.6$ ) diet overlaps between and within feeding guilds on account of diet similarities at different flooding stages (Tables 5-6). While juvenile (0-year-old) $O$. andersonii, $1+T$. rendalli and $H$. odoe were piscivores at increasing water levels and peak floods for T. rendalli (Fig. 6), the cichlids occupied significantly different (ANOVA: $P<0.05$ ) trophic levels compared to $H$. odoe. There was no overlap in their diet with H. odoe (Pianka's index <0.6) (Table 5).

Similarly, while significant diet overlaps (POI $>0.6)$ were observed between Clarias ngamensis and C. gariepinus,

ANOVA indicating food partitioning among different species (and different ages)

Table 5 at increasing water levels in the Boro River

\begin{tabular}{llllllllllll}
\hline & $\mathrm{N}-1$ & $\mathrm{~N}-2$ & $\mathrm{~N}-3$ & $\mathrm{M}-1$ & $\mathrm{G}-2$ & $\mathrm{G}-3$ & $\mathrm{~A}-0$ & $\mathrm{O}-1$ & $\mathrm{O}-2$ & $\mathrm{R}-1$ & $\mathrm{I}-2$ \\
\hline $\mathrm{N}-1$ & & & & & & & & & & & \\
$\mathrm{~N}-2$ & $\mathbf{0 . 1}$ & & & & & & & & & \\
$\mathrm{N}-3$ & $\mathbf{0 . 1}$ & 0.8 & & & & & & & & \\
$\mathrm{M}-1$ & 0 & 0.6 & 0.5 & & & & & & & \\
$\mathrm{G}-2$ & 0.2 & $\mathbf{0 . 6}$ & 0.5 & 0.8 & & & & & & \\
$\mathrm{G}-3$ & 0 & $\mathbf{0 . 6}$ & $\mathbf{0 . 6}$ & 0.7 & 1 & & & & & \\
$\mathrm{~A}-0$ & 0 & 0.1 & 0 & 0.5 & 0.2 & 0 & & & & \\
$\mathrm{O}-1$ & $\mathbf{0}$ & $\mathbf{0 . 3}$ & $\mathbf{0}$ & $\mathbf{0 . 2}$ & $\mathbf{0 . 2}$ & $\mathbf{0 . 1}$ & $\mathbf{0}$ & & & \\
$\mathrm{O}-2$ & $\mathbf{0}$ & $\mathbf{0 . 3}$ & $\mathbf{0}$ & $\mathbf{0 . 2}$ & $\mathbf{0 . 2}$ & $\mathbf{0 . 1}$ & $\mathbf{0}$ & 1 & & & \\
$\mathrm{R}-1$ & 0 & 0.2 & 0 & 0.5 & 0.2 & 0 & 0.8 & $\mathbf{0 . 5}$ & $\mathbf{0 . 5}$ & & \\
$\mathrm{I}-2$ & $\mathbf{0 . 3}$ & 0.3 & 0.1 & 0.4 & $\mathbf{0 . 3}$ & $\mathbf{0 . 1}$ & $\mathbf{0 . 3}$ & 0.9 & 0.9 & 0.7 & \\
$\mathrm{I}-1$ & $\mathbf{0}$ & 0.8 & 0.6 & 0.7 & $\mathbf{0 . 8}$ & $\mathbf{0 . 8}$ & 0 & $\mathbf{0 . 4}$ & $\mathbf{0 . 4}$ & 0.3 & 0.5 \\
\hline
\end{tabular}

Interactions showing significant differences in mean trophic level are marked in bold. The values are Pianka's overlap values derived from the Ecosim7 routine. NOTE: $\mathrm{N}-1=1+$ Clarias ngamensis, $\mathrm{N}-2=2+$ C. ngamensis, $\mathrm{N}-3=3+$ C. ngamensis; M-1 = 1+ Marcusenius macrolepidotus; G-2 = 2+ Clarias gariepinus, G-3 = 3+ C. gariepinus; A- $0=0+$ Oreochromis andersonii; $\mathrm{O}-1=1+$ Hepsetus odoe, $\mathrm{O}-2=2+$ H. odoe $; \mathrm{R}-1=1+$ Tilapia rendalli; $\mathrm{I}-2=2+$ Schilbe intermedius, $\mathrm{I}-1=1+$ S. intermedius. 


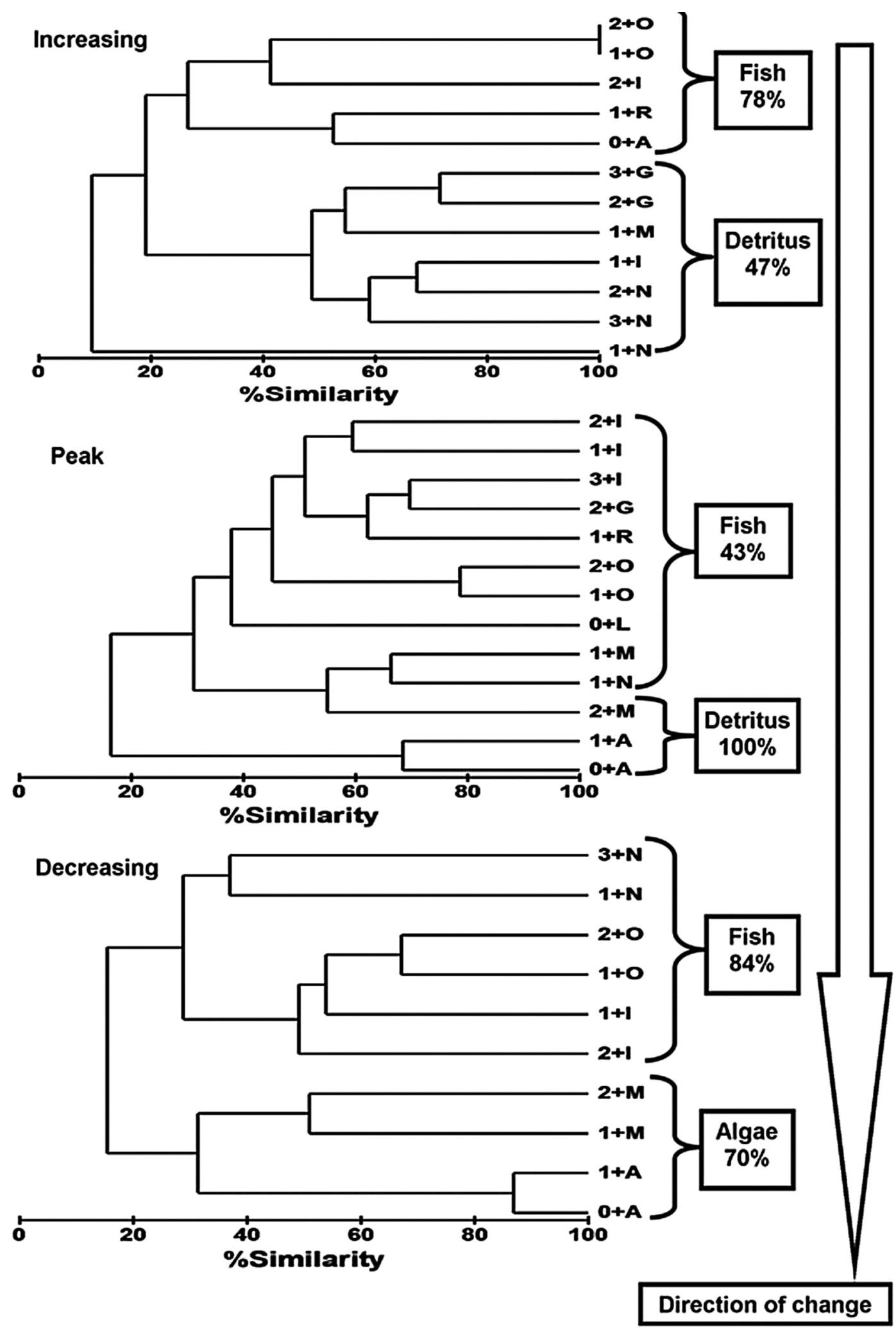

Fig. 6. Dendrogram using group-average linking on Bray-Curtis similarities illustrating species interactions (changes in diet guilds) over three flooding stages (increasing, peak floods and decreasing water levels) in the Boro River floodplains based on occurrence data; Note: $0+\mathrm{A}=0+$ Oreochromis andersonii; $1+\mathrm{A}=1+$ O. andersonii; $2+\mathrm{G}=2+$ Clarias gariepinus; $3+\mathrm{G}=3+$ C. gariepinus; $1+\mathrm{I}=1+$ Schilbe intermedius $; 2+\mathrm{I}=2+S$. intermedius; $3+\mathrm{I}=3+$ S. intermedius $; 0+\mathrm{L}=0+$ Brycinus lateralis; $1+\mathrm{M}=1+$ Marcusenius macrolepidotus; $2+\mathrm{M}=2+$ M. macrolepidotus; $1+\mathrm{N}=1+$ Clarias ngamensis; $2+\mathrm{N}=2+C$. ngamensis; $3+\mathrm{N}=3+$ C. ngamensis; $1+\mathrm{O}=1+$ Hepsetus odoe $; 2+\mathrm{O}=2+H$. odoe $; 1+\mathrm{R}=1+$ Tilapia rendalli 
these species occupied significantly different trophic levels. Some significant diet overlaps were observed between Marcusenius macrolepidotus and C. gariepinus, and they occupied similar trophic levels (ANOVA: $P>0.05$ ).

At peak floods, not only was there a significant diet overlap (POI $>0.6$ ) between 0 and $1+O$. andersonii, they also occupied the same trophic level (Table 6) in the "detritivorous" guild. However, there was perfect resource partitioning between $H$. odoe and other species in the "piscivorous" guild, where Pianka's diet overlap was 0 and there were significant differences (ANOVA: $P<0.05)$ in mean trophic level.

Water levels vs. feeding. There was no significant relation between Levin's index and mean trophic level $(P>0.05)$ with either mean water depth or discharge at Boro (Table 7) for Marcusenius macrolepidotus. However, there was a significant relation $(F=25.88 ; P \leq 0.05)$ between feeding rate and mean water depth, where $93 \%$ of the variations in feeding rates can be explained by changes in mean water depth. While the relations were not significant, diet scores from axis 1 of the DCA analysis responded more to discharge $(F=12.91 ; P=0.07)$ than to mean water depth $(F=0.01 ; P=0.93)$.

There were no significant relations $(P>0.05)$ between either discharge or mean water depth with either feeding rate (g per fish) or mean trophic level for Schilbe intermedius. However, there was a significant relation $(F=7.03$; $P \leq 0.05)$ between the feeding strategy of $1+S$. intermedius and water discharge, where $58 \%$ of the variations in the Levin's index was explained by discharge. There was a significant relation between diet scores of $1+S$. intermedius from axis 1 of DCA analysis and mean discharge $(F=7.12$; $P \leq 0.05)$ while none was observed between diet scores and mean water depth $(F=5.75 ; P=0.06)$.

\section{DISCUSSION}

Plasticity in diet is common in floodplain fish where most species feed on aquatic invertebrates and fish (Lowe-McConnell 1987). Our study agrees with this observation where fish species feed on a wide range of food items, with fish, algae and aquatic invertebrates as key prey, agreeing with previous studies from the Delta (Merron and Bruton 1988, Merron unpublished*). Earlier studies (Merron and Bruton 1988, Winemiller and KelsoWinemiller 2003) indicate that Tilapia rendalli is a herbivore grazing mostly on aquatic macrophytes (and algae), however, this study showed that it occasionally feeds on fish (apart from grass, seeds, algae and detritus) corroborating Skelton (2001). O. andersonii, which was previously described as a detritivore (Merron and Bruton 1988, Skelton 2001, Winemiller and Kelso-Winemiller 2003), preyed actively on Barbus spp. in a newly inundated Lake Ngami, which had been dry for 20 years. This feeding strategy suggests that most floodplain fish species (e.g., $O$. andersonii) are opportunistic and take advantage of available food resources for their survival.

Table 6

ANOVA indicating food partitioning among different species (and different ages) at peak floods and decreasing floods in the Boro River

\begin{tabular}{|c|c|c|c|c|c|c|c|c|c|c|c|c|c|c|}
\hline & $\mathrm{N}-1$ & $\mathrm{~N}-2$ & $\mathrm{~N}-3$ & M-1 & M-2 & G-2 & L-0 & A-0 & A-1 & O-1 & $\mathrm{O}-2$ & $\mathrm{R}-1$ & $\mathrm{I}-2$ & I-3 \\
\hline \multicolumn{15}{|l|}{$\mathrm{N}-1$} \\
\hline \multicolumn{15}{|l|}{$\mathrm{N}-2$} \\
\hline N-3 & $0.5^{\mathrm{d}}$ & & & & & & & & & & & & & \\
\hline M-1 & $0.4^{\mathrm{d}}$ & $0.8^{p}$ & $0.3^{\mathrm{d}}$ & & & & & & & & & & & \\
\hline M-2 & $0^{\mathrm{d}}$ & $0.6^{\mathrm{p}}$ & $0.3^{\mathrm{d}}$ & $0.8^{\mathrm{p}}, 0.7^{\mathrm{d}}$ & & & & & & & & & & \\
\hline $\mathrm{G}-2$ & & $0.3^{p}$ & & $0.2^{p}$ & $0.2^{p}$ & & & & & & & & & \\
\hline L-0 & & $0.1^{\mathrm{p}}$ & & $0.2^{\mathrm{p}}$ & $0.1^{\mathrm{p}}$ & $0.2^{\mathrm{p}}$ & & & & & & & & \\
\hline$A-0$ & $0^{\mathrm{d}}$ & $0.4^{p}$ & $0.3^{\mathrm{d}}$ & $0.4^{\mathrm{p}}, 0.8^{\mathrm{d}}$ & $0.1^{\mathrm{p}}, \mathbf{0 .} 7^{\mathrm{d}}$ & $0.4^{p}$ & $0.1^{p}$ & & & & & & & \\
\hline A-1 & $0^{\mathrm{d}}$ & $0.3^{p}$ & $0.3^{\mathrm{d}}$ & $0.3^{\mathrm{p}}, 0.6^{\mathrm{d}}$ & $0^{\mathrm{p}}, 0.4^{\mathrm{d}}$ & $0.3^{p}$ & $0^{\mathrm{p}}$ & $0.9^{\mathrm{p}}, 0.8^{\mathrm{d}}$ & & & & & & \\
\hline O-1 & $0.1^{\mathrm{d}}$ & $0^{p}$ & $0^{d}$ & $0^{p}, 0.1^{d}$ & $0^{p}, 0^{d}$ & $0.9^{p}$ & $0.2^{p}$ & $0^{p}, 0^{d}$ & $0^{p}, 0^{d}$ & & & & & \\
\hline $\mathrm{O}-2$ & $0.3^{\mathrm{d}}$ & $0^{p}$ & $\mathbf{0}^{\mathrm{d}}$ & $\mathbf{0}^{\mathrm{p}}, \mathbf{0 . 1 ^ { \mathrm { d } }}$ & $0^{p}, 0^{d}$ & $0.9^{p}$ & $0.2^{p}$ & $0^{p}, 0^{d}$ & $0^{\mathrm{p}}, \mathbf{0}^{\mathrm{d}}$ & $1^{\mathrm{p}}, 1^{\mathrm{d}}$ & & & & \\
\hline R-1 & & $0.2^{\mathrm{p}}$ & & $0.2^{\mathrm{p}}$ & $0.2^{\mathrm{p}}$ & $0.5^{\mathrm{p}}$ & $0.3^{p}$ & $0.3^{p}$ & $0.2^{\mathrm{p}}$ & $0.4^{p}$ & $0.4^{p}$ & & & \\
\hline $\mathrm{I}-2$ & $0.3^{\mathrm{d}}$ & $0.4^{p}$ & $0.2^{\mathrm{d}}$ & $0.4^{\mathrm{p}}, 0.2^{\mathrm{d}}$ & $0.4^{\mathrm{p}}, 0.2^{\mathrm{d}}$ & $0.8^{p}$ & $0.6^{\mathrm{p}}$ & $0.2^{\mathrm{p}}, 0.1^{\mathrm{d}}$ & $0.1^{\mathrm{p}}, 0^{\mathrm{d}}$ & $0.7^{\mathrm{p}}, 0.9^{\mathrm{d}}$ & $\mathbf{0 .} 7^{p}, 0.9^{d}$ & $0.4^{p}$ & & \\
\hline $\mathrm{I}-3$ & & $0.2^{\mathrm{p}}$ & & $0.3^{p}$ & $0.2^{\mathrm{p}}$ & $0.9^{p}$ & $0.3^{p}$ & $0.3^{p}$ & $0.3^{p}$ & $0.9^{p}$ & $0.9^{p}$ & $0.5^{p}$ & $0.9^{p}$ & \\
\hline I-1 & $0.1^{d}$ & $0.4^{p}$ & $0.1^{d}$ & $0.4^{\mathrm{p}}, 0.1^{\mathrm{d}}$ & $0.4^{\mathrm{p}}, 0^{\mathrm{d}}$ & $0.8^{p}$ & $0.6^{\mathrm{p}}$ & $0.2^{\mathrm{p}}, 0^{\mathrm{d}}$ & $0.1^{\mathrm{p}}, 0.1^{\mathrm{d}}$ & $\mathbf{0 . 7 ^ { p }}, 0.9^{d}$ & $0.7^{p}, 0.9^{d}$ & $\mathbf{0 . 4 ^ { \mathrm { p } }}, 0.9^{\mathrm{d}}$ & $0.8^{p}$ & $0.8^{p}$ \\
\hline
\end{tabular}

Interactions showing significant differences in mean trophic level are marked in bold. Superscripts p and d denote peak- and decreasing flood, respectively. The values are Pianka's overlap values derived from the Ecosim7 routine. NOTE: $\mathrm{N}-1=1+$ Clarias ngamensis, $\mathrm{N}-2=2+C$. ngamensis, $\mathrm{N}-3=3+$ C. ngamensis $; \mathrm{M}-1=1+$ Marcusenius macrolepidotus, $\mathrm{M}-2=2+$ M. macrolepidotus; G-2 $=2+$ Clarias gariepinus; L- $0=0+$ Brycinus lateralis; $\mathrm{A}-0=0+$ Oreochromis andersonii, $\mathrm{A}-1=1+O$. andersonii $; \mathrm{O}-1=1+$ Hepsetus odoe, $\mathrm{O}-2=2+$ H. odoe $; \mathrm{R}-1=1+$ Tilapia rendalli $; \mathrm{I}-2=2+$ Schilbe intermedius, $\mathrm{I}-3=3+S$. intermedius, $\mathrm{I}-1=1+S$. intermedius. 
Summary of linear regression analyses to establish the relation between various feeding indices of Schilbe intermedius and Marcusenius macrolepidotus against water depth and discharge

\begin{tabular}{lll}
\hline Test & S. intermedius & M. macrolepidotus \\
\hline Discharge vs. Levin's index & $0.045\left(R^{2}=0.58\right)^{*}$ & $0.17\left(R^{2}=68\right)$ \\
Depth vs. Levin's index & $0.11\left(R^{2}=0.43\right)$ & $0.17\left(R^{2}=68\right)$ \\
Depth vs. feeding rate [g per fish] & $0.89\left(R^{2}=0.00\right)$ & $0.04\left(R^{2}=0.93\right)^{*}$ \\
Discharge vs. feeding rate [g per fish] & $0.93\left(R^{2}=0.00\right)$ & $0.75\left(R^{2}=0.06\right)$ \\
Depth vs. trophic level & $0.53\left(R^{2}=0.10\right)$ & $0.35\left(R^{2}=0.42\right)$ \\
Discharge vs. trophic level & $0.88\left(R^{2}=0.01\right)$ & $0.26\left(R^{2}=0.55\right)$ \\
Discharge vs. Eigenvalues & $0.04\left(R^{2}=0.59\right)^{*}$ & $0.07\left(R^{2}=0.87\right)$ \\
Depth vs. Eigenvalues & $0.06\left(R^{2}=0.53\right)$ & $0.93\left(R^{2}=0.00\right)$ \\
\hline
\end{tabular}

Values with an * indicate a significant relation; g per fish $=$ grams of food eaten per fish.

Inter- and intra-specific interactions. Fish partition food between and within species (Labropoulou et al. 1999, de Merona and Rankin-de-Merona 2004), like floodplain fish in the Amazon where partitioning was more evident among specialized than generalized predators (de Merona and Rankin-de-Merona 2004). This study revealed that there was higher (significant: $P<0.05$ ) trophic segregation among species than within species, suggesting that inter-specific interactions might be the main driver structuring floodplain fish communities.

Significant inter-specific diet overlaps were observed in this study (e.g., Tilapia rendalli vs. Clarias ngamensis, Hepsetus odoe vs. Schilbe intermedius, etc.) which may suggest competition for food. However, H. odoe prefers quiet, deep (Skelton 2001), and slow flowing waters (Merron and Bruton 1988) in well vegetated backwaters (Winemiller and Kelso-Winemiller 1994, Merron unpublished*) while $S$. intermedius is a pelagic species (Merron and Bruton 1988) usually found among emergent or submerged vegetation (Skelton 2001). Furthermore, S. intermedius feeds nocturnally (Skelton 2001) relying on its sensory barbels and large eyes to actively seek its prey (Merron unpublished*) while $H$. odoe is a visual predator relying on light to find its prey (Skelton 2001). S. intermedius is also an aggressive predator with high habitat flexibility (Merron unpublished*) while $H$. odoe is an ambush predator that hides among vegetation waiting for its prey (Skelton 2001). Therefore, this observation suggests the possible existence of food partitioning based on feeding time. A similar observation was made in the Amazon (de Almeida et al. 1997) where niche differentiation among competitive species occurred through differences in feeding times, in habitat utilization, and by the ability of species like Rhaphiodon vulpinus Spix et Agassiz, 1829 (Characiformes) to have a greater "feeding flexibility". Diet similarity does not necessarily suggest direct competition for food, but rather that similar food resources are being used (Mathews et al. 1992) which might of course result in direct competition when food becomes limited.

That notwithstanding, except for Schilbe intermedius which is ubiquitous in the Delta (Merron unpublished*) and has a wide habitat preference (Skelton 2001), there is also trophic differentiation among these species which minimises contact and hence direct competition. That aside, piscivorous species prey on different fish species, of different ages, which is a clear case of resource partitioning that is otherwise not revealed through standard ecological indices. Lindholm and Hessen (2007) made a similar observation in the Delta's seasonal floodplain when they observed a potential diet overlap between larval Tilapia rendalli and Anisops sardea (aquatic insect in the order Hemiptera).

The trophic flexibility of some species and ontogenetic feeding of Clarias gariepinus minimises intra specific competition (for food) and optimise energy intake resulting in an efficient utilization of available food resources. While $C$. gariepinus was classified as an omnivore (Merron unpublished*), this study has revealed that twoyear-old fish were omnivores with a preference for animals $(\mathrm{TROPH}=3.3 \pm 0.47)$ while three-year-old fish were omnivores with a preference for plants (TROPH $=$ $2.7 \pm 0.43)$. The trophic partitioning between these age classes ensures co-existence through low (minimal) intraspecific competition. Merron's (Merron unpublished*) observation that larger (older) C. gariepinus (SL > 300 $\mathrm{mm}$ ) were piscivores compared to younger fish could have been biased by sampling "pack-hunting" catfish, which prey disproportionately on Marcusenius macrolepidotus during draw-down (Bell-Cross 1974, Merron 1993, Hanika and Kramer 2000) due to their electro-receptivity to electric discharges emitted by M. macrolepidotus (Hanika and Kramer 2000). While "pack-hunting" C. gariepinus were not sampled in this study, this seasonal feeding behaviour highlights the trophic flexibility of this species, driven by the flood pulse. This flood driven high trophic flexibility was also observed by Sá et al. (2006) in the Guadiana River estuary (in Portugal). While Merron (unpublished*) classified Schilbe intermedius as an insectivore and piscivorous predator, this study revealed that older fish (especially 3+'s) are piscivores while younger fish are omnivores. This suggests an ontogenetic feeding strategy by $S$. intermedius. 
The majority of fish species from other (floodplain) systems have an ontogenetic feeding strategy (GarcíaBerthou 1999, García-Berthou and Moreno-Amich 2000, Rossi 2001) which facilitates food resource partitioning (Garrison and Link 2000). However, overlap indices and trophic level analysis revealed minimal evidence of ontogenetic feeding among the species studied in the Delta. Apart from $S$. intermedius and $C$. gariepinus, no resource partitioning was observed within the other species, and there were significant overlaps in diet between older and younger fish in most of them. Winemiller and KelsoWinemiller (2003) also observed significant dietary overlaps between both juvenile and adult Oreochromis andersonii and Tilapia rendalli in the Zambezi River. That notwithstanding, Stergiou and Karpouzi's (2002) fractional trophic levels revealed the existence of ontogenetic diet shifts within several species in this study. What is particularly important to note is that the system (i.e., the Okavango Delta) is not static, but is dynamically driven by seasonal (and inter-annual) flooding patterns. Therefore, while potential for inter- and intra-specific competition might exist in floodplain fish communities, this is mediated by the flood pulse, which disperses fish into new habitats opened by new floods. According to Amarasekare (2003), fish dispersal (caused by floods' arrival) into new habitats reduces competition in the fish community. This strong seasonality suggests that competition within floodplain fish communities is in constant flux in tandem with the seasonal rhythms of the flooding patterns. Generally, inter- and intra-specific competition for food increase at low water levels when fish become more concentrated in the water body and food resources become more limited (Lowe-McConnell 1987). Conversely, high water levels improve habitat connectivity, which improves habitat partitioning by species and age class, and subsequently food partitioning (and availability), which would then decrease competition for food.

Generally, while mean TROPH values per species increased with increasing size, similar to other studies (Stergiou and Karpouzi 2002, Simon et al. 2009), some species such as $C$. gariepinus and $O$. andersonii showed an opposite trend where younger fish occupied higher trophic levels than older fish. Furthermore, Brycinus lateralis, (the smallest species studied) occupied higher trophic levels than some large sized species. Layman et al. (2005) explains that some predators are able to exploit prey at energetically optimal sizes by occupying low trophic positions due to variations in prey body size, morphology and habitat affinity. This feeding strategy then results in non-linearity between body size and trophic level position. Barbus spp. (especially Barbus paludinosus Peters, 1852) are pioneer species and would have therefore been the most available prey (food) item for younger (smaller-sized) $O$. andersonii (these are able to colonise recently inundated habitats better) than older (larger-sized) fish in Lake Ngami (which was newly inundated). In this scenario, which epitomises a classical opportunistic feeding strategy, younger fish occupy high- er trophic levels than older fish within the same species. This observation accentuates the highly dynamic opportunistic feeding behaviour of floodplain fish species, where dynamism is the main constant for survival in a highly fluctuating system.

Cannibalism has been reported for Hydrocynus vittatus Castelnau, 1861 (Alestidae) and Hepsetus odoe (see Merron and Bruton 1988, Winemiller and KelsoWinemiller 1994, Skelton 2001), and this was also observed for S. intermedius in this study. Winemiller and Kelso-Winemiller (1994) observed that H. odoe cannibalism in the Zambezi River occurs at decreased water levels while this study showed that older $S$. intermedius exhibited cannibalism (around July) at relatively high water levels (in Boro). Possibly, most hetero-specific species (e.g., cyprinids, mormyrids, etc.) migrate to shallow floodplains, hence reducing their availability to larger (older) $S$. intermedius. In this scenario, where there is low abundance of hetero-specific prey, Rudolf (2008) argues that cannibalism increases, which would explain cannibalism within the $S$. intermedius community during this time. However, this cannibalism might also be caused by what Claessen et al. (2004) define as size dependent interactions. In Winemiller and Kelso-Winemiller's (1994) case, the $H$. odoe cannibalism might be caused by intra-specific competition (Claessen et al. 2004), which is normally high at low water levels due to decreased food supply. Cannibalism in S. intermedius and Clarias ngamensis (observed in the Delta), suggests that this behaviour might be more widespread than observed before in floodplain fish communities. Dynamic changes in the fish community structure, caused by seasonal flooding may facilitate this behaviour. Cannibalism in predators might cause non-linearity in predator-prey interactions in fish communities (Rudolf 2008) and therefore its impact across trophic levels needs to be understood before it can be integrated into food web theory. Generally, if cannibalism, is stronger than predation, this may alter trophic cascades in the fish community where prey survival increase because predation effects are dampened by cannibalism. It is particularly striking that cannibalism appears to be higher in ubiquitous and abundant species in the Okavango Delta (e.g., S. intermedius, C. gariepinus, and C. ngamensis). This suggests that this "short-circuited predator-system" may be the main strategy used by catfishes to enhance their survival in seasonal floodplains and increase their comparative advantage over other species.

Spatio-temporal variations in feeding behaviour. Spatio-temporal variations in food items (observed in this study) highlight fluxes in food availability at spatial and temporal scales (Sá et al. 2006) caused by seasonal flooding. Generally, terrestrial food sources (e.g., ants, grasshoppers, mice, etc.) were eaten more either at increasing or peak water levels, while aquatic food sources (e.g., fish, algae, etc.) were consumed more at decreasing water levels by Schilbe intermedius. This feeding strategy, which is strongly regulated by the seasonal flood pulse, affirms the impact of the flood pulse on the 
feeding ecology of fish species in flood-pulsed environments. These seasonal variations in feeding ecology are caused by migrations (horizontal and vertical) observed by Merron (unpublished*) due to the seasonal flood regime. That notwithstanding, this diet flexibility ensures that optimum net energy intake is maintained throughout the year. Subsequently, this opportunistic feeding strategy ensures less spatio-temporal variations in mean trophic levels, which was observed for Marcusenius macrolepidotus and $S$. intermedius. These species are effectively utilizing available food resources in different habitats to maintain their energy requirements.

The dynamic aquatic-terrestrial ecotone allows for seasonal changes in the feeding strategy of $S$. intermedius in relation to variations in water depth. At high water levels, $S$. intermedius is a generalist predator eating a wide variety of food items but switches to specialised predation, preying predominantly on fish at receding water levels. This increased piscivory at reduced water levels was also observed for $1+$ and $3+$ Clarias ngamensis and $1+$ and $2+$ Hepsetus odoe. The increased preference for fish at this time suggests that piscivory is enhanced by "concentration" effects in fish availability observed by Welcomme (1985) in floodplain fisheries. This dynamic change in feeding strategy by floodplain fish is observed by de Merona and Rankin-de-Merona (2004) in the Amazon, where Triportheus spp. (Characiformes) narrowed their diet in the low water season. Vaz et al. (1999) also observed similar changes in the feeding strategy of some detritivorous fish species in the Parana River system (Brazil) which had broad feeding niches at high floods that narrowed considerably at low floods. Temporal changes in feeding strategy were also discussed by Merron (unpublished*) who observed a higher presence of terrestrial food sources (e.g., mice, termites, Orthoptera, etc.) at increasing flood levels, than at receding floods. Being an active predator, it is anticipated that $S$. intermedius' diet responds more to changes in water discharge than depth. The basic assumption being that its prey items are flushed out into the water column by rapidly advancing water (e.g., drowning mice, ants) in the inundated floodplains. Similarly, fish prey (especially some cyprinids) might respond more to changes in water flow rates (e.g., Hladík and Kubečka 2003) at decreasing water levels which would make them more vulnerable to predation. This increased piscivory at reduced water levels results in a lengthening of the food chain, which in turn results to a less efficient energy transfer. It follows then, that (some) fish may generally lose body condition during this time, until the next flooding season.

Similarly, Marcusenius macrolepidotus feeding strategy changes from a generalist predator at high water levels to a more specialist feeder grazing (almost exclusively) on algae at low water levels. Merron and Bruton (1988) observe that M. macrolepidotus back-migrate to the main channel from drying up floodplains, and this might explain the switch in feeding strategy. This dependence on algae is similar to Finlay et al. (2002) observa- tions who observed that trout growth was highly dependent on algal production during low water levels in summer. The presence of seeds in the diet of M. macrolepidotus agrees with the observation of Chick et al (2003) that floodplain fish take advantage of resources in the aquatic-terrestrial ecotone, and may indeed be agents of seeds dispersal. While it has never been known to prey on fish (even algae) in the Delta (Merron and Bruton 1988, Skelton 2001), the presence of fish in M. macrolepidotus diet at decreased water levels suggested that it also takes advantage of the "concentration" effect of fish at low water levels. The observation that M. macrolepidotus feeding rate responded more to water depth suggests that it takes advantage of the inundated floodplains to feed heavily (on abundant food items) before back migrating to the channel and lagoon habitats at receding (low) water levels, where food is less abundant. This observation is consistent with Lowe-McConnell (1987) who observed that high water is the main feeding (and growing) time for most floodplain fish.

There is evidence that the terrestrial environment is actively subsidizing the aquatic system (i.e., fish species feed on terrestrial food sources) as a consequence of the flood pulse. Possibly because of habitat switching between the different life history stages, and perhaps due to flooding variability, the Delta's fish species are opportunistic feeders actively channelling terrestrial carbon into fish biomass. This is illustrated by Clarias gariepinus feeding on Diplopoda (millipedes) and mice; Schilbe intermedius feeding on mice, ants, and grasshoppers; and C. ngamensis feeding on ants, grasshoppers, and other terrestrial insects. Moreover, the presence of bird remains in the diet of one-year-old S. intermedius and Brycinus lateralis also attests to this opportunistic feeding strategy. These broad (and opportunistic) feeding strategies are possibly an adoptive strategy against an unpredictable system. Specialised feeding strategies would undoubtedly make the different fish species more vulnerable to changes in the environment, which might affect their survivability. This adoptive strategy agrees with Moss (1980) who observes that several Lake Chilwa fish species have "very" broad diets and unspecialized habitat requirements which allow them to cope with the lake's irregular drying out phases. This study has validated Lowe-McConnell's (1987) observations that riverine fish species have an opportunistic feeding behaviour because of the ephemeral nature of habitats and food resources. Furthermore, opportunistic feeding ensures less cost in searching for food, and optimisation of energy intake during periods of scarcity (Corrêa et al. 2009). Ultimately, floodplain fish species are major conduits of energy flow from the terrestrial to the aquatic environment. This study has validated the effect of the flood pulse on the feeding ecology of floodplain fish. Subject to further investigations, this study has shown that inter- and intra-specific competition for food is a dynamic process driven by the flood pulse. 


\section{CONCLUSIONS}

This study has shown that the terrestrial-aquatic ecotone, driven by the seasonal flood pulse, is important towards fish growth in seasonal floodplains where food of terrestrial origin is channelled into fish diet. This affirms Lowe-McConnel's (1987) observations that a large proportion of floodplain fish species rely on floodplain ecotone resources. Therefore, any future upstream management plans need to ensure that this ecotone is maintained for the sustainable production of fish biomass. Another key observation made from this study is that energy uptake is optimised through cannibalism to ensure species survival into successive generations. Furthermore, the feeding behaviour of different fish species is constantly morphing to take advantage of environmental variations which affect food availability. Generally, food chains are short at the start of the flood cycle and lengthen at reduced water levels. This dynamic relation occurs more at decreased water levels when predation and competition (inter- and intra-) increase in the fish community. While the competition theory based on Lotka-Volterra's model predicts species extinction in uniform, stable environments (Begon et al. 1986), Tilman's mechanistic model suggests that a species' competitive ability is regulated by its ability to utilise a limiting resource (Lampert and Sommer 2007). However, these key ecological models are negated by the flood pulse driven feeding behaviour of floodplain fish species, where the system is in constant flux.

This study highlights Lowe-McConnell's (1987) discussions on the maintenance and evolution of tropical fish assemblages. Are floodplain assemblages driven by deterministic processes where food partitioning facilitated by competition (including predation and cannibalism) is the major force structuring tropical fish communities? Evidence from this study has shown that predation, cannibalism and (inter-specific) competition are major attributes of floodplain fish communities. This study has contributed to floodplain fish feeding ecology theory, and also highlights the dynamic processes involved in floodplain fish feeding ecology, and the need for intensive and long term studies which will ultimately aid in management of this key resource. In conclusion, this study has also affirmed Marshall and Eliot's (1997) argument that several techniques should be used to evaluate fish feeding ecology.

\section{ACKNOWLEDGEMENTS}

This study was funded from Project R524 from the Office of Research and Development (ORD) at the University of Botswana. Gratitude is also expressed to Drs. Mike-Murray Hudson and Richard Fynn who reviewed earlier drafts of this paper. Great appreciation is also given to Mr M. Dhliwayo and Mrs A. Makati from the ORI GIS lab who assisted in production of map and figures in this manuscript.

\section{REFERENCES}

Agostinho C.S., Hahn N.S., Marques E.E. 2003. Patterns of food resource use by two congeneric species of piranhas
(Serrasalmus) on the upper Paraná River floodplain. Brazilian Journal of Biology 63 (2): 177-182. DOI: $10.1590 / \mathrm{S} 1519-69842003000200002$

Amarasekare P. 2003. Competitive coexistence in spatially structured environments: a synthesis. Ecology Letters 6 (12): 1109-1122. DOI: 10.1046/j.1461-0248.2003.00530.x

Baldoa F., Drake P. 2002. A multivariate approach to the feeding habits of small fishes in the Guadalquivir Estuary. Journal of Fish Biology 61 (Suppl. sA): 21-32.

DOI: $10.1111 / j .1095-8649.2002 . t b 01758 . x$

Baremore I.E., Murie D.J., Carlson J.K. 2010. Seasonal and size-related differences in diet of the Atlantic angel shark Squatina dumeril in the northeastern Gulf of Mexico. Aquatic Biology 8 (2): 125-136.

DOI: $10.3354 / \mathrm{ab} 00214$

Begon M., Harper J.L., Townsend C.R. 1986. Ecology; individuals, populations and communities. Blackwell, Oxford, UK.

Begon M., Mortimer M. 1986. Population ecology; a unified study of animals and plants. Blackwell, London, UK.

Bell-Cross G. 1974. A fisheries survey of the upper Zambezi River system. Occasional Papers of the National Museums and Monuments of Rhodesia B5 (5): 279-338.

Bunn S.E., Thoms M.C., Hamilton S.K., Capon S.J. 2006. Flow variability in dryland rivers: boom, bust and the bits in between. River Research and Applications 22 (2): 179-186. DOI: 10.1002/rra.904

Chick J.H., Cosgriff R.J., Gittinger L.S. 2003. Fish as potential dispersal agents for floodplain plants: first evidence in North America. Canadian Journal of Fisheries and Aquatic Sciences 60 (12): 1437-1439.

DOI: $10.1139 /$ f03-155

Claessen D., Roos A.M., Persson L. 2004. Population dynamic theory of size-dependent cannibalism. Proceedings of the Royal Society of London, Part B: Biological Sciences 271 (1537): 333-340.

DOI: $10.1098 / \mathrm{rspb} .2003 .2555$

Clarke K.R., Gorley R.N. 2001. PRIMER v5 (\& v6): User manual/tutorial, PRIMER-E. Plymouth, UK.

Corrêa C.E., Hahn N.S., Delariva R.L. 2009. Extreme trophic segregation between sympatric fish species: the case of small sized body Aphyocharax in the Brazilian Pantanal. Hydrobiologia 635 (1): 57-65.

DOI: $10.1007 / \mathrm{s} 10750-009-9861-2$

de Almeida V.L.L., Hahn N.S., de Vazzoler A.E.A. 1997. Feeding patterns in five predatory fishes of the high Paranà River floodplain (PR, Brazil). Ecology of Freshwater Fish 6 (3): 123-133.

DOI: $10.1111 / j .1600-0633.1997 . t b 00154 . x$

de Graaf G. 2003. The flood pulse and growth of floodplain fish in Bangladesh. Fisheries Management and Ecology 10 (4): 241-247.

DOI: 10.1046/j.1365-2400.2003.00341.x

de Merona B., Rankin-de-Merona J.R. 2004. Food resource partitioning in a fish community of the central Amazon floodplain. Neotropical Ichthyology 2 (2): 75-84. DOI: $10.1590 / \mathrm{S} 1679-62252004000200004$

Eberle L.C., Stanford J.A. 2010. Importance and seasonal availability of terrestrial invertebrates as prey for juvenile 
salmonids in floodplain spring brooks of the Kol River (Kamchatka, Russian Federation). River Research and Applications 26 (6): 682-694.

DOI: $10.1002 /$ rra.1270

Feinsinger P., Spears E.E., Poole R.W. 1981. A simple measure of niche breadth. Ecology 62 (1): 27-32. DOI: $10.2307 / 1936664$

Finlay J.C., Khandwala S., Power M.E. 2002. Spatial scales of carbon flow in a river food web. Ecology 83 (7): 1845-1859.

DOI: 10.1890/0012-9658(2002)083[1845:SSOCFI]2.0.CO;2

Froese R., Binohlan C. 2000. Empirical relationships to estimate asymptotic length, length at first maturity and length at maximum yield per recruit in fishes, with a simple method to evaluate length frequency data. Journal of Fish Biology 56 (4): 758-773.

DOI: $10.1111 /$ j.1095-8649.2000.tb00870.x

García-Berthou E. 1999. Food of introduced mosquitofish: ontogenetic diet shift and prey selection. Journal of Fish Biology 55 (1): 135-147.

DOI: 10.1111/j.1095-8649.1999.tb00663.x

García-Berthou E., Moreno-Amich R. 2000. Food of introduced pumpkinseed sunfish: ontogenetic diet shift and seasonal variation. Journal of Fish Biology 57 (1): 29-40. DOI: $10.1111 /$ j.1095-8649.2000.tb00773.x

Garrison L.P., Link J.S. 2000. Diets of five hake species in the northeast United States continental shelf ecosystem. Marine Ecology Progress Series 204: 243-255.

DOI: $10.3354 / \mathrm{meps} 204243$

Gotelli N.J., Entsminger G.L. 2007. EcoSim: Null models software for ecology. Version 7. Acquired Intelligence Inc. and Kesey-Bear, Jericho, VT, USA. Available at http://garyentsminger.com/ecosim/index.htm

Hanika S., Kramer B. 2000. Electrosensory prey detection in the African sharptooth catfish, Clarias gariepinus (Clariidae), of a weakly electric mormyrid fish, the bulldog (Marcusenius macrolepidotus). Behavioral Ecology and Sociobiology 48 (3): 218-228.

DOI: $10.1007 / \mathrm{s} 002650000232$

Hladík M., Kubečka J. 2003. Fish migration between a temperate reservoir and its main tributary. Hydrobiologia 504 (1-3): 251-266.

DOI: 10.1023/B:HYDR.0000008525.46939.42

Hoeinghaus D.J., Winemiller K.O., Layman C.A., Arrington D.A., Jepsen D.B. 2006. Effects of seasonality and migratory prey on body condition of Cichlia species in a tropical floodplain river. Ecology of Freshwater Fish 15 (4): 398-407. DOI: $10.1111 / \mathrm{j} .1600-0633.2006 .00152 . x$

Hyslop E.J. 1980. Stomach contents analysis - a review of methods and their application. Journal of Fish Biology 17 (4): 411-429.

DOI: $10.1111 /$ j.1095-8649.1980.tb02775.x

Junk W.J. 1996. Ecology of floodplains - a challenge for tropical limnology. Pp. 255-265. In: Schiemer F., Boland K.T. (eds.) Perspectives in tropical limnology. SPB Academic Publishers, Amsterdam, the Netherlands.

Junk W.J., Bayley P.B., Sparks R.E. 1989. The flood pulse concept in river-floodplain systems. Pp. 110-127. In: Dodge D.P. (ed.).
Proceedings of the International Large River Symposium. Canadian Special Publication in Fisheries Aquatic Science No. 106.

Kolding J., van Zwieten P.A.M. 2005. Improving productivity in tropical lakes and reservoirs. Challenge Program on Water and Food - Aquatic Ecosystems and Fisheries Review Series 1. World-Fish Centre, Cairo.

Labropoulou M., Machias A., Tsimenides N. 1999. Habitat selection and diet of juvenile red porgy, Pagrus pagrus (Linnaeus, 1758). Fisheries Bulletin 97 (3): 495-507.

Lampert W., Sommer U. 2007. Limnoecology: the ecology of lakes and streams. Oxford University Press, Oxford, UK.

Layman C.A., Winemiller K.O., Arrington D.A., Jepsen D.B. 2005. Body size and trophic position in a diverse tropical food web. Ecology 86 (9): 2530-2535.

DOI: $10.1890 / 04-1098$

Lindholm M., Hessen D.O. 2007. Competition and niche partitioning in a floodplain ecosystem: a cladoceran community squeezed between fish and invertebrate predation. African Zoology 42 (2): 158-164. DOI: 10.3377/1562-7020(2007)42[158:CANPIA]2.0.CO;2

Lowe-McConnell R.H. 1987. Ecological studies in tropical fish communities. Cambridge University Press, Cambridge, UK.

Marshall S., Elliot E. 1997. A comparison of univariate and multivariate numerical and graphical techniques for determining inter- and intraspecific feeding relationships in estuarine fish. Journal of Fish Biology 51 (3): 526-545.

DOI: $10.1111 / \mathrm{j} .1095-8649.1997 . t b 01510 . x$

Mathews W.J., Gelwick F.P., Hoover J.J. 1992. Food and habitat use by juveniles of species of Micropterus and Morone in a Southwestern Reservoir. Transactions of the American Fisheries Society 121 (1): 54-66. DOI: 10.1577/1548-8659(1992)121<0054:FOAHUB >2.3.CO;2

McCune B., Mefford M.J. 1999. Multivariate analysis of ecological data, Version 4.24. Gleneden Beach, OR, USA.

Merron G.S. 1993. Pack-hunting in two species of catfish, Clarias gariepinus and C. ngamensis in the Okavango Delta, Botswana. Journal of Fish Biology 43 (4): 575-584. DOI: $10.1111 / j .1095-8649.1993 . t b 00440 . x$

Merron G.S., Bruton M.N. 1988. The ecology and management of the fishes of the Okavango delta, Botswana, with special reference to the role of the seasonal floods. J.L.B. Smith Institute of Ichthyology, Grahamstown, South Africa. Investigational Report No. 29.

Mosepele K., Nengu S. 2004. Growth, mortality, maturity and length-weight parameters of selected fishes from the Okavango Delta, Botswana. Pp. 67-74. In Pauly D., Diouf B., Samb B., Vakily M.J., Palamores M.L.D. (eds.) Fish biodiversity: Local studies as basis for global inferences. ACP-EU Fisheries Research Initiative. Brussels, Belgium.

Mosepele K., Mosepele B., Bokhutlo T., Amutenya K. 2011. Spatial variability in fish species assemblage and community structure in four subtropical lagoons of the Okavango delta, Botswana. Physics and Chemistry of the Earth, 36 (14-15): 910-917.

DOI: $10.1016 /$ j.pce.2011.07.060

Moss B. 1980. Ecology of freshwaters; man and medium. Blackwell, London, UK. 
Navia A.F., Mejía-Falla P.A., Giraldo A. 2007. Feeding ecology of elasmobranch fishes in coastal waters of the Colombian Eastern Tropical Pacific. BMC Ecology 7 (8): [10 pages without official numbering.] DOI: $10.1186 / 1472-6785-7-8$

Ney J.J. 1993. Practical use of biological statistics. Pp 137-177. In: Kohler C.C., Hubert, W.A. (eds.) Inland fisheries management in North America. American Fisheries Society, Bethesda, MD, USA.

Odum H.T. 1994. Ecological and general systems: an introduction to systems ecology. University Press of Colorado, Niwot CD, USA.

Odum E.P., Barret G.W. 2005. Fundamentals of ecology. 5th edn. Thompson Brooks/ Cole, Pacific Grove, CA, USA.

Pauly D., Froese R., Sa-a P.S., Palomares M.L., Christensen V., Rius J. 2000. TrophLab Manual. ICLARM, Manila, Philippines.

Ramberg L., Wolski P., Krah M. 2006. Water balance and infiltration in a seasonal floodplain in the Okavango Delta, Botswana. Wetlands 26 (3): 677-690. DOI: 10.1672/0277-5212(2006)26[677:WBAIIA]2.0.CO;2

Ricklefs R.E. 1990. Ecology. 3rd edn. Freeman and Company, New York, NY, USA.

Roach K.A., Winemiller K.O., Layman C.A., Zeug S.C. 2009. Consistent trophic patterns among fishes in lagoon and channel habitats of a tropical floodplain river: Evidence from stable isotopes. Acta Oecologica 35 (4): 513-522. DOI: $10.1016 /$ j.actao.2009.03.007

Rosas-Alayala J., Hernández-Herrera A., Galvan-Magaña F., Abitia-Cárdenas L.A., Muhlia-Melo A.F. 2002. Diet composition of sailfish (Istiophorus platypterus) from the southern Gulf of California, Mexico. Fisheries Research 57 (2): 185-195. DOI: $10.1016 / \mathrm{S} 0165-7836(01) 00344-7$

Rossi L.M. 2001. Ontogenetic diet shifts in a neotropical catfish, Sorubim lima (Schneider) from the River Paraná System. Fisheries Management and Ecology 8 (2): 141-152. DOI: 10.1046/j.1365-2400.2001.00237.x

Rudolf V.H.W. 2008. The impact of cannibalism in the prey on predator-prey systems. Ecology 89 (11): 3116-3127. DOI: 10.1890/08-0104.1

Sá R., Bexiga C., Veiga P., Vieira L., Erzini K. 2006. Feeding ecology and trophic relationships of fish species in the lower Guadiana River Estuary and Castro Marim e Vila Real de Santo António Salt Marsh. Estuarine Coastal and Shelf Science 70 (1-2): 19-26. DOI: $10.1016 /$ j.ecss.2006.05.038

Simon K.D., Bakar Y., Samat A., Zaidi C.C., Aziz A., Mazlan A.G. 2009. Population growth, trophic level, and reproductive biology of two congeneric archer fishes (Toxotes chatareus, Hamilton 1822 and Toxotes jaculatrix, Pallas 1767) inhabiting Malaysian coastal waters. Journal of Zhejiang University SCIENCE B 10 (12): 902-911. DOI: $10.1631 /$ jzus.B0920173
Skelton P.H. 2001. A complete guide to freshwater fishes of southern Africa. Struik Publishers, Cape Town, Republic of South Africa.

Stergiou K.I., Karpouzi V.S. 2002. Feeding habits and trophic levels of Mediterranean fish. Reviews in Fish Biology and Fisheries 11 (3): 217-254.

DOI: $10.1023 / \mathrm{A}: 1020556722822$

Vaz M.M., Petrere M., Martinelli L.A., Mozeto A.A. 1999. The dietary regime of detritivorous fish from the River Jacaré Pepira, Brazil. Fisheries Management and Ecology 6 (2): 121-132. DOI: 10.1046/j.1365-2400.1999.00123.x

Vázquez R.I., Rodríguez J., Abitia L.A., Galván F. 2008. Food habits of the yellow snapper Lutjanus argentiventris (Peters, 1869) (Percoidei: Lutjanidae) in La Paz Bay, Mexico. Revista de Biología Marina y Oceanografía 43 (2): 295-302.

Watanabe H., Kubodera T., Kawahara S. 2003. Feeding habits of Pacific pomfret Brama japonica in the transition zone of the central North Pacific. Fisheries Science 69 (2): 269-276.

DOI: 10.1046/j.1444-2906.2003.00617.x

Welcomme R.L. 1979. Fisheries ecology of floodplain rivers. Longman Publishers, New York, NY, USA.

Welcomme R.L. 1985. River Fisheries. FAO Fisheries Technical Paper No. 262. FAO, Rome.

Winemiller K.O., Kelso-Winemiller L.C. 1994. Comparative ecology of the African pike, Hepsetus odoe, and tiger-fish, Hydrocynus forskahlii, in the Zambezi River floodplain. Journal of Fish Biology 45 (2): 211-225.

DOI: $10.1111 / j .1095-8649.1994 . t b 01301 . x$

Winemiller K.O., Kelso-Winemiller L.C. 2003. Food habits of tilapiine cichlids of the upper Zambezi River and floodplain during the descending phase of the hydrologic cycle. Journal of Fish Biology 63 (1): 120-128.

DOI: 10.1046/j.1095-8649.2003.00134.x

Wolski P., Murray-Hudson M. 2005. Flooding dynamics in a large low-gradient alluvial fan, the Okavango Delta, Botswana, from analysis and interpretation of a 30 year hydrometric record. Hydrology and Earth System Sciences J1 - HESS 10: 127-137.

Wolski P., Savenije H.H.G., Murray-Hudson M., Gumbricht T. 2006. Modelling of the flooding in the Okavango Delta, Botswana, using hybrid reservoir-GIS model. Journal of Hydrology 331 (1-2): 58-72.

DOI: $10.1016 /$ j.jhydrol.2006.04.040

Zalewski M., Thorpe J.E., Naiman R.J. 2001. Fish and riparian ecotones - a hypothesis. Ecohydrology and Hydrobiology 1 (1-2): 11-24.

Received: 25 January 2012

Accepted: 9 October 2012

Published electronically: 31 December 2012 